\title{
A Review of Waste Management Options in Olive Oil Production
}

\section{NURI AZBAR, ABDURRAHMAN BAYRAM, AYSE FILIBELI, AYSEN MUEZZINOGLU, FUSUN SENGUL and ADEM OZER}

Department of Bioengineering, Ege University, Bornova, Izmir, Turkey

Department of Environmental Engineering, Dokuz Eylul University, Kaynaklar Campus, Buca, Izmir, Turkey Address correspondence to Aysen Muezzinoglu, Dokuz Eylul University, Faculty of Engineering, Department of Environmental Engineering, Kaynaklar Campus, 35160 Buca, Izmir, Turkey. E-mail: aysen.muezzin@deu.edu.tr

In this article, treatment and disposal alternatives of olive oil mill wastes and technical requirements for their management are covered. Waste characteristics, treatment options with regard to the economic feasibility, and challenges of existing waste disposal practices in olive growing countries are mentioned. Attention is drawn to present-day techniques of waste management. The search concerning the environmentally acceptable, economically feasible, and practically applicable methods of disposal of olive oil mill wastes is referred. In the management schemes, compliance with environmental regulations and economic and social benefits of the olive oil production are the goals that must be simultaneously achieved.

KEY WORDS: mill wastewaters; olive oil; olive wastes; treatment economy; waste combustion; wastewater treatment. 


\section{INTRODUCTION}

\subsection{General}

Recent archeological findings off the northern coast of Israel gave details on the olive oil production knowledge of the ancient inhabitants of the Mediterranean areas. According to this research the Neolithic dwellers of this region invented the usage of olives between 8000 and 7000 years ago. $\frac{28}{}$

Olive oil is nearly totally produced in the Mediterranean region. Three quarters of the annual production in the world comes from European Union countries around the Mediterranean Sea. As the demand of olive oil is rapidly increasing worldwide, environmental pollution posed by olive mill wastes (OMW) is a growing problem especially in the Mediterranean region. The olive oil producer countries have been facing a serious challenge to find an environmentally sound and economically viable solution in handling and disposal of OMW.

Solid and liquid OMW are dark-colored wastes and contain high amounts of organic materials. They are composed of many complex substances that are not easily degradable. Production facilities are usually associated with emissions of strongly odorous volatile compounds. When their wastes are disposed into the environment, they create odor nuisance, too. Deterioration of natural water bodies due to olive oil mill wastes is a serious problem as indicated by coloring, appearance of an oily shine, and increased oxygen demand. They also affect the soil quality, are toxic to plant life, and create odor nuisance when disposed into the soil. Therefore, direct discharge of olive mill wastewaters into receiving media is not permissible and certain measures must be taken before disposal of the OMW into the environment.

Main problem regarding the disposal of OMW is to find an environmentally friendly and economically viable solution. In biochemical treatment of these olive oil mill wastewaters, high capital and operating cost units with limited efficiency have to be installed due to high organic loads and high chemical oxygen demand (COD) to biological oxygen demand (BOD) ratios. Due to the presence of toxic organics mostly coming from the broken seeds, these wastes are toxic to bacteria and direct biological treatment is not possible. $\frac{32}{\text { In }}$ addition, these wastes are mostly generated from small enterprises having limited financial resources and usually far from each other. The latter creates difficulty in establishing central treatment and disposal facilities.

On the other hand, there are studies indicating that OMW may also be regarded as an economic resource. Among these practices, use of OMW as soil conditioner, biomass fuel, compost, or as starting material to obtain valuable products such as antioxidants, enzymes and biogas fuel may be counted. Recycle and reuse of process water for irrigation purposes may also be considered, but acceptable water quality must be guaranteed.

In order to avoid the economic and social chaos leading to potential crisis in olive production due to the requirements of very expensive OMW treatment investments, several provisory legislation and ministerial decrees were promulgated and strategic plans were applied in some countries. One of them has foreseen spreading of wastewaters on land, such as in Italy. Spain almost totally changed the production techniques from press and three-phase (oil-water-paste) continuous systems to two-phase systems to produce less waste. Extensive field studies and research indicating the high fertilizing and soil conditioning value of OMW were carried out in Spain and Italy. .57

Even though three-quarters of world olive oil is produced in the European Union, having stringent environmental regulations, there is still need to establish an international normative to impose a common strategy among the olive oil producer countries in the Mediterranean basin. Such a regulation should safeguard the environmental values without harming the small producers and olive oil markets.

\subsection{The Olive Tree}

The olive tree grows almost exclusively around the Mediterranean Sea. This tree has been praised by every civilization around the Mediterranean. The olive tree (Olea europaea) is a small evergreen tree that averages 3 to $5 \mathrm{~m}$ in height. In general, cultivating olive trees takes time, as the first sizeable crop is expected after 8 to 10 years; however, there are some varieties that are giving excellent olive production in 4-6 years. The tree bears small, creamy white flowers in May and has characteristic small leaves: pale green above and silvery below. The olive fruit starts maturing in October, when it may be harvested for table olive as pickled green olive. It then slowly turns black until December and is consumed as salted or pickled black olives or is sent to oil production. The composition of olives is given in Table 1. Olive fruit has a stony pit containing $30 \%$ lipids, $20 \%$ carbohydrates, and 50\% systemic water. 
TABLE 1 Composition of Parts of the Olive Fruit ${ }^{26}$ (Adapted)

Constituents $\quad$ Pulp (\%) $\quad$ Stone (\%) $\quad$ Seed (\%)

$\begin{array}{lccc}\text { Water } & 50-60 & 9.3 & 30 \\ \text { Oil } & 15-30 & 0.7 & 27.3 \\ \text { Nitrogen containing compounds } & 2-5 & 3.4 & 10.2 \\ \text { Sugar } & 3-7.5 & 41 & 26.6 \\ \text { Cellulose } & 3-6 & 38 & 1.9 \\ \text { Minerals } & 1-2 & 4.1 & 1.5 \\ \text { Polyphenols (aromatic compounds) } & 2-2.25 & 0.1 & 0.5-1 \\ \text { Others } & - & 3.4 & 24\end{array}$

The olive tree yield is greatly affected by a biennial cycle: One year it grows and the other year gives more fruits. Therefore, more olive oil and wastes are generated every other year. This irregularity of the olive harvest is primarily due to biological factors inherent in this cyclic tree crop, and to a lesser extent due to climatic conditions specific to the Mediterranean basin. Although progress has been made in cultivation methods during the last 30 years, aimed at improving the production, erratic crop years and market supplies are still a problem. .31

\subsection{Uses and Ingredients}

For centuries olive oil was used as a major part of the Mediterranean diet, for medicine, and as lamp fuel. Nowadays, it is increasingly consumed for nutritional purposes and its derivatives are used in modern cosmetics.

Harvested olives for oil production were traditionally ground to a paste in mills consisting of stone wheels on a granite slab. The paste was pressed between straw disks under high pressure. Finally, the oil was decanted or more recently centrifuged to eliminate residual water and solids, yielding extra virgin olive oil.

The major use of olive oil is as food, although medicinal properties of olive oil have been recognized for centuries. Minor ingredients are important for the stability and flavor of the oil. Oil from high-quality fresh olives containing low levels of organic acids is called "extra virgin olive oil." Microclimate plays an important role in determining the oil quality and oils from different regions have different tastes and flavors. If the oil contains high acidity, it is neutralized in plants called "refineries." Refined olive oil usually lacks most of the minor components and loses the beneficial vitamins and flavors. It is blended with virgin oils to give special tastes.

Olive oil relieves burns or stings, and is also a good vehicle for liniments in external use. Baby skin benefits greatly from its nourishing properties. For thousands of years, soap makers around the Mediterranean created the olive oil soap by using pure olive oil and alkaline ash from local plants. Such soap is still renowned for its moisturizing properties and gentleness, and is particularly recommended for cleansing dry or sensitive skin and hair as well as delicate fabrics. Ingredients derived from olive oil are still used in cleansing and cosmetic products. Some ingredients are also known for superior nutritional value and medicinal uses. Perhaps the most striking recent hypothesis is that olive oil can help to prevent some types of cancers. $\stackrel{2}{\text { Researchers who }}$ compared diets with cancer incidences in 28 countries around the world and studied food and cancer databases statistically linked olive oil consumption to less cancer. ${ }^{47}$ It was also suggested that several constituents of olive oil, such as squalene, flavonoids, and polyphenols, are likely to protect humans against cancer. $\frac{38}{}$

Useful ingredients in olive oil that have a variety of applications ranging from pharmaceuticals to cosmetics are as follows: 


\section{Olive unsaponifiables}

The nonglycerol or fatty acid components in the olive oil are called "unsaponifiable" matter. It accounts for $1.5-2 \%$ and its major constituent is squalene. Epidemiological studies of populations in the Mediterranean region suggest that several types of cancer are lower in areas with high intake of olive oil, yet more thorough studies are required to prove that squalene is an antitumor ingredient of the olive. "Vegelane" is one of the most stable lipids usable in cosmetics, also an excellent pigment dispersing agent and a valuable fixative for perfumes. "Tocolive" is an olive unsaponifiable substance that consists mostly of squalene and contains $1 \%$ of tocopherols.

\section{Waxes and butters}

Olive waxes and butters are obtained by catalytic hydrogenation of olive oil. Waxolive and beurrolive are two products obtained from olive oil and are excellent viscosity modifiers used in cosmetics. Candolive is a special quality of waxolive, developed for candle making and offering excellent burning properties. ${ }^{71}$

\section{Olive leaf}

Olive leaf is a source of several antioxidants. The major one is oleuropein, which has been demonstrated to have strong antimicrobial properties with potential applications for the treatment of intestinal or respiratorytract infections in humans. ${ }^{12}$ Studies conducted by pharmaceuticals researchers identified the primary ingredient "calcium elenolate" in oleuropein as the active agent. A pharmaceuticals research company then developed and patented a process for extracting $d$-elenolic acid. This ingredient marketed under various trade names is becoming widely recognized for the important part it can play in helping to fight a broad spectrum of disease-causing pathogens and thereby boosting the immune system. ${ }^{71}$

\subsection{Present-Day Production}

The olive oil sector requires improvements in environmental and quality profiles of the whole production chain for economic competitiveness.

The olive is an environmentally friendly fruit; high quantities of chemicals are unnecessary for its growth and less energy is required for its processing. Olive oil production is expected to be environmentally friendly due to the low-energy and chemicals-free manufacturing process, too. However, generation of large quantities of highly polluted wastes during processing of olives is inevitable.

Mediterranean countries of the European Community, led by Spain, produce 10 million tons per year, which is $75 \%$ of the world olive harvest. In terms of olive oil this share is about $18.8 \%$, amounting to 1.8 million tons per year, and the total waste generation is nearly $75 \%$ of the olive harvest. ${ }^{26}$ Therefore, environmentally sound disposal of OMW originating from the biannual production of olive oil during a short harvesting period has priority in the agenda of the Mediterranean countries.

\subsection{Research and Development}

Several research teams such as the Universidad Complutense de Madrid in Spain have been working on safe disposal techniques for OMW. They also work with the European Commission and have organized an international workshop, Improlive-2000. Another group of researchers from the Environmental and Energy Engineering Department of the University of Sheffield, United Kingdom, has also been working on a project that commenced in September 2000 with the name of "Alternative Uses of Olive Oil Mill Wastes." Likewise, a research team is established in Dokuz Eylul University, Izmir, Turkey, led by the authors of this article, to actively work on wastewater disposal strategies and combustion system design for solid wastes for small olive oil enterprises that are geographically distributed in the Aegean region of Turkey. 


\section{OLIVE OIL MANUFACTURING AND OLIVE OIL MILL WASTE MANAGEMENT}

\subsection{Manufacturing Processes and Waste Generation}

Olive oil production is carried out in "mills." Mill wastes are composed of solid wastes consisting of olive pulp and pits left over after pressing the fruits, as well as liquid wastes consisting of vegetable and additional water generated during decantation. Batch (press) and continuous processes are the main methods used in olive oil production. Depending on the separation method used in continuous operation, two technologies are recognized: two- and three-phase processes. These processes mainly differ in the process water requirements. In three-phase systems process water is added and three phases (oil, wastewater, solid wastes in the form of an olive cake) are produced. A two-phase plant, however, involves two phases (oil and water-solid mixture) and much less additional water is used than in the three-phase process. $\frac{61}{}$ The olive oil production processes are summarized in Figure 1.

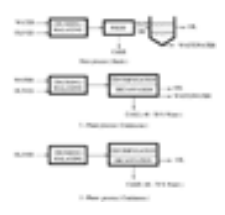

FIGURE 1 Olive oil extraction processes (adapted from the information in reference 22).

[Medium View]

\section{[Enlarged View]}

In the traditional press process, the olives are washed, crushed, and kneaded with the addition of hot water. The resulting paste is then pressed to drain the oil. The liquid waste originating from presses consists of a mixture of olive juice and added water and contains residual oil. Finally, olive oil is separated from the water by vertical centrifugation or decanting. .22 Pressed solids is a cake that can be further de-oiled elsewhere. This requires special facilities. De-oiled solids are usually burned for energy, and oil is sold for soap manufacture or for edible oil if the quality is assured after refining. Press technology is the traditional olive oil extraction process, which needs little water but produces highly polluted wastewaters. Even today, a significant part of the world olive oil production is still achieved by press technology.

In the continuous process, a horizontal centrifuge allows continuous operation. The main advantages of the continuous centrifugation process with respect to the traditional press technology are increased production, minimized labor cost, smaller space requirement, better quality due to elimination of mat flavor, improved process control, and ease in automation. But it has high capital cost compared to press technology. Table 2 shows the main parameters for different production techniques of olive oil.

TABLE 2 Approximate Input-Output Data for the Three Types of Olive Oil Production Processes $\frac{26}{2}$ (Adapted)

$\begin{array}{llll}\text { Production process } \quad \text { Input } & \text { input } & \text { Output }\end{array}$

$\begin{array}{llll}\text { Traditional press } & \text { Olives } & 1 \text { ton } & \text { Oil }\end{array}$

process

$\begin{array}{llll}\text { Wash water } & 0.1-0.12 \mathrm{~m}^{3} & \begin{array}{l}\text { Solid waste }(25 \% \\ \text { water }+6 \% \text { oil })\end{array} & 400 \\ \text { Energy } & 40-63 \mathrm{kWh} & \begin{array}{l}\text { Wastewater }(88 \% \\ \text { water + solids and oil) }\end{array} & 600\end{array}$

$\begin{array}{llll}\text { Three-phase process } & \text { Olives } & 1 \text { ton } & \text { Oil }\end{array}$

Wash water $\quad 0.1-0.12 \mathrm{~m}^{3} \quad$ Solid waste $(50 \% \quad 500-600$ 


$$
\text { water }+4 \% \text { oil) }
$$

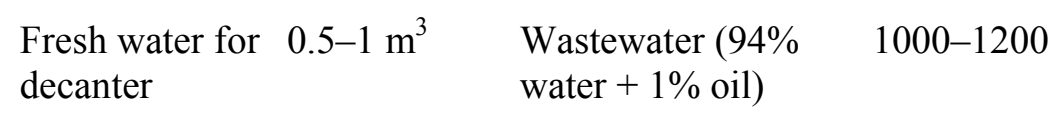

\author{
Water to polish $10 \mathrm{~L}$ \\ the impure oil
}

$$
\text { Energy } \quad 90-117 \mathrm{kWh}
$$

$\begin{array}{llll}\text { Two-phase process } & \text { Olives } & 1 \text { ton } & \text { Oil }\end{array}$

Washing water $\quad 0.1-0.12 \quad \begin{aligned} & \text { Solid }+ \text { water waste } 800-950 \\ & (60 \% \text { water }+3 \% \text { oil })\end{aligned}$

\title{
Energy $\quad<90-117 \mathrm{kWh}$
}

Solid phases obtained in continuous processes are quite rich in water; $30-50 \%$ in the three-phase system and $60-70 \%$ in the two-phase system, respectively. Wastes also contain $2-4 \%$ of residual olive oil. $\underline{6}$ Economy of de-oiling and use of olive solids as fuel is possible for three-phase and press process solids, only, as the moisture content of two-phase solids is high. However, high water requirements and resulting wastewater volumes are important factors in considering the use of three-phase system for olive oil production.

A three-phase process generates olive mill wastewater volumes of about three times more than the press system. While $0.4-0.6 \mathrm{~m}^{3}$ wastewater is produced per ton of product in the press process, wastewater production is up to $1.0-1.2 \mathrm{~m}^{3}$ in the three-phase process. However, press system results in a wastewater more concentrated in pollutants compared to the three-phase system. In the two-phase process, however, wastewater is less in quantity and originates mainly from washing water. The two-phase system is called "ecological" by some people because of less water and energy requirements and its comparably reduced pollution load. However, problems related with disposal of mixed solid-liquid waste from these systems have not been completely solved. Mixed OMW is less in overall quantity, but treatment of the mixed solid and liquid wastes is not easier. Besides, it is not possible to separate the solids and send them to de-oiling facilities.

The two-phase technology was supported by national policies in Spain aimed at minimizing the high costs of wastewater handling and disposal. ${ }^{14}$ The system has benefited from public funding for implementation. The other olive oil producing countries are also slowly adopting this technology. It is suggested that two-phase technology saves process water by $80 \%$, and energy up to $20 \%$. It requires less investment cost by as much as $25 \%$ compared to the three-phase system. This technology creates a mixed solid-liquid waste called alpeorujo in Spanish. This mixed waste contains about $60 \%$ water and 3\% oil.

Yet some of the small olive oil enterprises resist switching to the two-phase process, especially if water economy is not a major consideration. Some manufacturers claim that water addition is always necessary to meet the required traditional olive oil quality. Still another case is that of premises equipped with already existing three-phase centrifugation capacity. For these reasons, switching into two-phase from three-phase technology is difficult, and some producers prefer to continue using the three-phase process. A permitted twophase plant may easily be operated as a three-phase plant.

\subsection{Properties of Wastes from Olive Oil Production}

As the names of waste streams differ from one country to another, a standardized terminology regarding olive processing wastes does not exist. Depending on the country of origin of the publication, several duplicating terms are in use in the literature. In this article, standard environmental engineering terminology is used throughout.

Characteristics of olive oil mill wastewater vary widely with regard to the oil production method. For example, its quantity varies between 50 and $700 \mathrm{~L} /$ ton of pressed olives, and COD concentration varies between 5 and $25 \mathrm{~g} \mathrm{~L}^{-1}$ of wastewater in two-phase olive oil mills. These ranges are 900-1500 $\mathrm{L} \mathrm{ton}^{-1}$ olive and 50-90 $\mathrm{g} \mathrm{L}^{-1}$ for three-phase plants, respectively.

Wastewaters from olive oil industry have the following general properties:

- Intensive dark brown to black color. 
- Strong acidic smell unique to olives.

- High organic content (COD values around $220 \mathrm{~g} \mathrm{~L}^{-1}$ in three-phase units) and a COD/BOD ratio between 2.5 and 5, indicating low biodegradability.

- Acidic character with $\mathrm{pH}$ values between 3 and 5.9.

- High concentrations of phenolic compounds (up to $80 \mathrm{~g} \mathrm{~L}^{-1}$ ).

- High content of solid matter (total solids up to $20 \mathrm{~g} \mathrm{~L}^{-1}$ ).

The properties of the wastewaters from two-phase process are summarized in Table 3. Literature data concerning the constituents of a three-phase olive mill wastewater is given in Table 4 , and wastewater compositions for both press technology and three-phase continuous processes are given in Table 5 .

TABLE 3 Characteristics of Different Types of Mixed Wastewater-Solid Waste (Alpeorujo) from Two-Phase Processes $\underline{26}$ (Adapted)

Parameters

Mixed wastewater- Stone-free mixed solid waste
De-oiled stone-free mixed waste
Mixed waste dried at $400^{\circ} \mathrm{C}$

*Lower heating value.

\begin{tabular}{|c|c|c|c|c|}
\hline $\mathrm{pH}$ & $5.3-5.8$ & 4.87 & 5.00 & 5.80 \\
\hline Ash, $\%$ wt & $7.10-7.46$ & 7.65 & 9.12 & - \\
\hline Lipids, \% wt & 4.34 & 7.18 & 6.38 & 12.48 \\
\hline Proteins, $\% \mathrm{wt}$ & $13.56-14.80$ & 9.44 & 8.65 & 15. \\
\hline Sugars, \% wt & $1.30-2.31$ & 1.48 & 1.21 & 1.87 \\
\hline Tannins, $\% \mathrm{wt}$ & $1.25-2.70$ & 2.18 & 2.61 & 1.33 \\
\hline Nitrogen, \% wt & $2.48-3.16$ & 2.10 & 1.96 & 3.08 \\
\hline $\mathrm{LHV}_{-}^{*}$; kcal kg${ }^{-1}$ & 27.61 & 15.04 & 22.45 & \\
\hline
\end{tabular}

TABLE 4 Characteristics of Wastewaters from Three-Phase Process (Adapted from Individual Research Works in Reference 26)

Chemical oxygen demand (COD), $\mathrm{g} \mathrm{L}^{-1}$ 
Total solids (TS), $\mathrm{g} \mathrm{L}^{-1}$

Organic total solids (OTS), $\mathrm{g} \mathrm{L}^{-1}$

Fats, $\mathrm{g} \mathrm{L}^{-1}$

Polyphenols, $\mathrm{g} \mathrm{L}^{-1}$

$0.002-80$

Volatile organic acids, $\mathrm{g} \mathrm{L}^{-1}$

$0.78-10$

Total nitrogen, $\mathrm{g} \mathrm{L}^{-1}$

$0.3-1.2$

TABLE 5 Characteristics of Wastewaters from Press and Three-Phase Processes ${ }^{60}$

$\mathrm{pH}$

Total solids, $\%$

Volatile suspended solids, \%

Mineral suspended solids, $\%$

Suspended solids, \%

Chemical oxygen demand, $\mathrm{g} \mathrm{L}^{-1}$

Biochemical oxygen demand, $\mathrm{g} \mathrm{L}^{-1}$

Sugars, \%

Total nitrogen, $\%$

Polyalcohols, \%

Pectin, tannin, $\%$

Polyphenols, \%

Oil and grease, $\%$

Oil mill wastewater is of serious environmental concern in many par content and associated treatment costs. There are restrictions against dumping agricultural wastes into city sewers or receiving water bodies such as rivers and uncontrolled reservoirs. In some countries regulatory provisions let a certain amount of olive oil mill wastewater to be used in the olive plantations provided it does not have a negative impact on the tree growth and the water supply systems. There are efforts and research studies trying to make use of the potassium, phosphorus, and other trace elements in these wastewaters in agriculture. However, one should keep in mind that untreated wastewaters contain lipids, salinity, and phenolic compounds that have negative effects on soil and plants in the long run and should not be directly 
used for agricultural purposes. It must be kept in mind that rehabilitation of soil is neither practical nor feasible once it is contaminated.

\subsection{Integral Olive Oil Mill Waste Management}

A research team at the University of Valladolid (Spain) has developed the concept of the "integral olive mill" (IOM), mainly with the aim to solve the ecological problems. This plant dries the raw wastes from a twophase mill by mechanical means to the moisture content of $50 \%$ to simulate a three-phase mill olive cake and extracts the oil remaining in the cake. The IOM process includes energy optimization options to save energy by using the olive stones as fuel, and recovery of the waste heat for internal use. Wastewater is treated to use the effluents in olive plantations for irrigation, and the sludge fraction is sent to composting or animal fodder manufacturing plants. Alternatively, elimination of the liquid effluent is possible in the evaporation ponds. However, costs incurred for water reuse can be a critical decision factor in the final evaluation of the IOM process. Total independence from additional combustion fuels, reuse of combustion ashes as mineral fertilizers, $\stackrel{22}{2}$ and evaluation of the residual cake as organic fertilizer after composting are still under discussion.

\subsection{Waste Minimization Practices}

Waste minimization possibilities in olive oil mills are also investigated by several researchers. Studies especially aim at reduction of the water use. Although some researchers claim that two-phase is a pollution prevention method from this point of view, it is doubtful as it creates a substantial quantity of a thick liquid which is not easier to treat than the separate wastewater and solid phases. Two-phase techniques also endanger the solid waste de-oiling facilities operating like reclamation units. The only feasible option for the waste of two-phase process seems to use it in composting.

For other waste minimization studies, Vlyssides and coworkers ${ }^{70}$ proposed destoning of the olive fruits before malaxation, which would decrease the quantity of wastewater and eliminate most of the toxic ingredients. However, it is rather early to comment on this idea as the research cited has not been based on plant tests. No comment on the success of destoning machinery is available in this citation either.

Water reuse due to partly or completely treated olive oil mill wastewater is the most basic waste minimization practice. Liquid product from evaporation-distillation as discussed in this article may be recycled to the olive oil mill and may be used to wash the incoming olives or even used in the process provided the taste is not negatively affected. Residual oil extraction from the solid wastes carried out in separate plants is an example of reclamation practice. Resulting oil is used in soap manufacturing or mixed with edible oils if it has good quality. De-oiled wastes can be used as fuel, provided the design of the furnaces is suitable to burn these wastes. In some studies these wastes are burned in dual feeding furnaces together with other fuels. In another study proposals were made for modification of the system design to allow cleaner combustion in existing energy systems of olive oil industry. $\underline{\underline{23}}$

\subsection{Wastewater Treatment and Disposal Alternatives}

\subsubsection{GENERAL}

Olive mill wastes have a primary importance from the environmental point of view. These wastes can be considered as both a resource to be recovered and a waste to be treated. Wastewaters from olive oil mills have high organic matter, suspended solids, and lipid contents and are produced at high flow rates. Many scientists work on efficient and cost-effective treatment alternatives. To achieve this goal, several alternatives and their combinations were tested including the chemical, mechanical, physical, biological, and thermal methods.

Several treatment methods such as physicochemical, chemical, biological (aerobic or anaerobic), evaporation (natural or forced), and land application are considered. Beneficial use of olive mill wastewater and its end products is anticipated, such as by recycling the treated water, and using the residues as fertilizer either directly or after composting or as raw material for antioxidant production. $\frac{53}{3}$ Treatment sludge can be utilized as fuel either by burning directly or after biogas production.

Although a successful and economic treatment alternative could not be suggested yet, storage and evaporation in lagoons is the most common method for the disposal of olive mill wastewaters. In this method, the wastewater is stored in lagoons during the olive mill operation, which lasts for about 3 months, and liquid fraction is evaporated during the approaching summer season. The main disadvantages of this option are the odor caused by emissions of volatile organic compounds and fly nuisance.

\subsubsection{CHEMICAL COAGULATION/FLOCCULATION}

In chemical treatment studies of olive mill wastewater, different coagulants such as ferric chloride, aluminum chloride, ferrous sulfate, calcium hydroxide, and their combinations sometimes added by different anionic 
polyelectrolytes and sulfuric acid were tested by several researchers. For example, COD and suspended solid removal efficiencies of $50-90 \%$ were obtained in a chemical treatment study. $\frac{59}{}$

\subsubsection{LAND APPLICATION}

Some researchers have shown that the controlled spreading of raw wastewaters on agricultural land may have a positive effect on the olive plantations, as well as on other crops such as grape wine, corn, or sunflower. However, this practice is to be considered only after a thorough evaluation of all of the environmental impacts. For example, experiments with $1000 \mathrm{~m}^{3} \mathrm{ha}^{-1}$ per year or more of raw wastewaters laid on limestone containing Spanish soils have resulted in an increase in organic matter, total and soluble nitrogen, available phosphorus, and salts. But it also increased the mobility of heavy metals, and caused lixiviation of sodium and nitrate into deep soil, which are unwanted effects. On the other hand, when low wastewater volumes, such as of the order of $100 \mathrm{~m}^{3} \mathrm{ha}^{-1}$ per year are used, it is suggested that the soil could act as a biofilter for the treatment of olive oil wastewaters. ${ }^{22}$

\subsubsection{EVAPORATION-HYDROLYSIS-OXIDATION (EHO)}

A group of researchers collaborated to develop the evaporation-hydrolysis-oxidation (EHO) method for the treatment of olive mill wastewaters. In this method, following a preconcentrating step by evaporation, hydrolysis under controlled heat input and subsequent oxidation by air take place. EHO process is carried out in several steps:

- Removal of the sludge for utilization in pulp oil manufacturing and fuel production.

- Removal of residual fatty acids as much as possible by means of a ceramic ultrafiltration membrane.

- Removal of substances with phytotoxic effects from the wastewater.

- Recovery of materials that could be used for the production of industrial oils or as fuel.

- Collection and transportation of olive oil wastewaters, and further treatment of the water obtained if necessary.

The EHO process is at the prototype development stage. The capital investment of a pilot plant treating olive oil wastewaters from a Greek district with an average olive oil production of 1400 tons per year was given as about 14 million Euros with an annual operating cost of nearly 1 million Euros..$^{39}$

\subsubsection{MEMBRANE PROCESSES}

Membrane filtration such as reverse osmosis or ultrafiltration is applied on olive mill wastewaters after some pretreatment steps. In this case, wastewater is separated into two phases: treated wastewater (permeate), and concentrate (retentate). The concentrate can be sent to incineration or landfilled for final disposal. ${ }^{39}$

\subsubsection{ELECTROLYSIS}

This method is based on in situ production of strong oxidizing hydroxyl radicals, which can oxidize organics to carbon dioxide and water in an electrolysis cell using a Ti/Pt anode and stainless steel 304 cathode. A number of experiments were run in a batch laboratory-scale pilot plant, in which reductions of total chemical oxygen demand (COD), total organic carbon (TOC), volatile suspended solids (VSS), and phenolic compounds were investigated. After $10 \mathrm{~h}$ of electrolysis, COD removal of $93 \%$, TOC removal of $80.4 \%$, VSS reduction of $98.7 \%$, and phenolic compound removal of $99.4 \%$ were reported. The mean energy consumption was calculated as $12.3 \mathrm{kWh} / \mathrm{kg}$ COD removed for $10 \mathrm{~h}$ electrolysis period. These results indicated that electrolysis of olive mill wastewaters could be used as a pretreatment stage followed by chemical treatment or another advanced oxidation process, which should be used for detoxification and mineralization of wastewater. $\stackrel{40}{ }$

In another electrochemical treatment study for olive mill wastewater, the possibility of oxidizing the phenols and polyphenols at a $\mathrm{PbO}_{2}$ anode was tested. It was possible to reduce the concentration of the phenolic components down to a noninhibiting level for biological growth. Therefore, this electrochemical method was successful as a pretreatment alternative to be applied before the traditional biological treatment. ${ }^{45}$

\subsubsection{VACUUM EVAPORATION}

Vacuum evaporation is another alternative disposal method for olive mill wastewaters. A study was reported ${ }^{44}$ in which a vacuum of $5 \mathrm{kPa}$ allows the wastewater to evaporate at low temperatures such as $38^{\circ} \mathrm{C}$. The vacuum evaporator produces two streams: a continuously produced distillate, and a discontinuous concentrate automatically discharged. Wastewater was neutralized using sodium hydroxide during distillation. Distilled water volume reached to $90 \%$ of the wastewater input. The distillate was a colorless liquid but had COD of 
$3000-4000 \mathrm{mg} \mathrm{L}^{-1}$, which still required further treatment. Biological oxidation of the distillate preceded by $\mathrm{pH}$ adjustment and $\mathrm{C}: \mathrm{N}: \mathrm{P}$ correction gave a treated water complying with the wastewater discharge regulations. The concentrate can be mixed with the solid residues from olive oil mill. This mixture can either be de-oiled and burned or used for various purposes such as animal fodder or fertilizer, as it contains $14 \%$ protein and $5 \%$ potassium.

\subsubsection{NATURAL EVAPORATION}

Natural evaporation requires extended storage time for wastewaters, depending on the climatic conditions of the area. For 2 tons of olive processed, $1 \mathrm{~m}^{3}$ of lagoon volume is required for storage and natural evaporation in Izmir, Turkey. ${ }^{43}$ The main disadvantages of natural evaporation are the fly and odor nuisances, as well as potential groundwater contamination if the bottom of the storage lagoon is not properly lined against infiltration. Lagooning is not the preferred method on these grounds in Spain. In a study in Portugal, vacuum evaporation panels consisting of plates with $30^{\circ}$ inclination were fixed into a lagoon in order to separate solid and liquid phases. The liquid phase was evaporated while solid the phase remained on the plates and was taken out in order to be used as fertilizer. $\underline{\underline{24}}$

\subsubsection{ANAEROBIC TREATMENT}

Because of the high organic content of olive oil mill wastewaters, anaerobic treatment processes with biogas production are considered by many researchers. However, the presence of oil and antimicrobial phenolic compounds creates a challenge for biological treatment. $\frac{32}{37}, \frac{31}{6}, \underline{65}, \underline{73}$ Olive oil mill wastewaters are strong in chemical oxygen demand (COD), but deficient in nitrogen. Carbon:nitrogen:phosphorus (C:N:P) ratios of the wastewaters from press and centrifugation systems are 100:1.77:0.94 and 100:1.34:0.70, respectively. Inhibitory effects due to low $\mathrm{pH}$ and the build up of volatile fatty acids during storage could create problems in anaerobic digestion. ${ }^{3}$ In spite of these negative features for biological treatment, olive oil mill wastewaters are quite amenable for anaerobic treatment after pretreatment and adjustment of composition. Anaerobic treatment has several advantages, such as low sludge generation, methane gas production, less energy requirement for operation, and easy restart after several months of shutdown before seasonal production campaigns.

Recently, there have been several attempts for performing anaerobic olive mill wastewater digestion studies

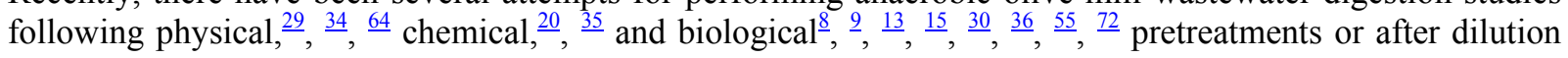
and chemical adjustment ( $\mathrm{pH}$ correction and nutrient addition). Co-digestion with other agro-industry wastes

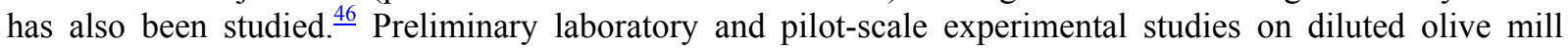
wastewaters showed that the anaerobic contact process could give high organic removal efficiencies ranging between 80 and $85 \%$ at $35^{\circ} \mathrm{C}$ at organic loads (COD) less than $4 \mathrm{~kg} \mathrm{~m}^{-3} \mathrm{~d}^{-1}$. But for highly concentrated mill effluents, the process proved unstable due to the inhibitory effects of ingredients such as polyphenols and potassium. Moreover, additions of alkali substances to neutralize acidity and ammonia to furnish nitrogen for cellular biosynthesis were necessary.

To overcome the difficulties and improve process efficiency and stability there are basically two methods that may be adopted. ${ }^{9}$

1. Treating olive mill wastewaters and sewage sludge mixture in contact bioreactors.

2. Treating diluted olive mill wastewaters in high-rate bioreactors such as up-flow anaerobic sludge blanket (UASB) reactors and fixed-bed filters.

A laboratory-scale study showed that at an organic (COD) loading rate of $4.2 \mathrm{~kg}^{-3} \mathrm{~d}^{-1}$ at $35^{\circ} \mathrm{C}$ with mixed olive mill waste (34\%) and sewage sludge, a COD removal efficiency of $65 \%$ could be obtained. ${ }^{19}$ Higher portions of wastewater additions caused imbalances of the process due to inhibitory effects of polyphenols. It can be concluded that the co-digestion of olive mill wastewater and sewage sludge seems to be a suitable solution.

In a study performed on olive mill wastewaters and residual solids in batch type of reactors, biochemical methane potential (BMP) tests were conducted to determine the anaerobic biodegradability. ${ }^{25}$ With these tests the biodegradability of wastewaters at different initial chemical oxygen demand concentrations and corresponding methane gas productions were measured. The results indicated that olive mill wastewaters could be treated anaerobically with high efficiencies (COD removal of 85.4-93.4\%) and by producing $57.1 \pm$ $1.5 \mathrm{~L}$ methane gas per liter of olive mill wastewater. This literature also cited that the anaerobic treatment of the olive mill residual solids alone was poor; however, when they were mixed with olive oil mill wastewaters at certain ratios, treatment efficiency gets better. Anaerobic cultures needed an adaptation period of 15-25 days for treatment of solid wastes. 
The up-flow anaerobic sludge bed (UASB) reactor is the most suitable type of anaerobic reactor to treat olive mill wastewaters. Experimental studies showed that at $37^{\circ} \mathrm{C}$ and at an organic load in the COD range of 12$18 \mathrm{~kg} \mathrm{~m}^{-3} \mathrm{~d}^{-1}$, removal efficiencies of about $70-75 \%$ were obtained by adopting a dilution ratio varying between $1 / 8$ and $1 / 5$. Dilution ratio is the volume of olive mill wastewater with initial concentration in the COD range of $11-19 \mathrm{~g} \mathrm{~L}^{-1}$ divided by the volume of tap water added. ${ }^{8}$ Although suspended growth systems like UASB or completely mixed reactors were more advisable than fixed-bed systems for treatment of olive mill wastewaters, $\frac{58}{,} \frac{67}{,} \frac{68}{6}$ studies with fixed-bed systems were also carried out. Anaerobic digestion of a mixture of olive mill wastewater $(80 \%)$ plus piggery effluent $(20 \%)$ was performed in an up-flow anaerobic filter. ${ }^{46}$ This study indicated $70-80 \%$ treatment efficiency for influent COD varying between 20 and $60 \mathrm{~g} \mathrm{~L}^{-1}$. The process provided the neutralization of influent, as well as the conversion of $50-70 \%$ of its phenolics content. Experimental studies indicated that the effluent can be used for agricultural irrigation purposes.

Beccari and coworkers ${ }^{9}$ showed that the production of methane gas was inhibited by the presence of lipids in anaerobic treatment of olive mill wastewaters. A semicontinuous laboratory scale two-reactor system was operated with diluted olive mill wastewater. This flow scheme that allows the separation of acidogenesis and methanogenesis phases provided an almost quantitative biotransformation of unsaturated long-chain fatty acids to palmitic acid in the first reactor, thus drastically lowering lipid inhibition on methanogenesis in the second reactor.

Several tests were performed on the phenolic ingredients of olive mill wastewaters, such as tyrosol, oleuropein, and caffeic, $p$-hydroxybenzoic, and protocatechuic acids in order to see the relationship with methane formation. In a study by Borja et al. $\frac{16}{}$ these substances were added at various concentrations to aliquots of domestic anaerobic sludge in Hungate serum bottles and were incubated at $35^{\circ} \mathrm{C}$. Methane concentrations in the headspace gas were measured to see if the phenols were fermented to methane or if they inhibited the anaerobic process. It was found that only tyrosol and $p$-hydroxybenzoic acid were fermented to methane. At $600 \mathrm{mg} \mathrm{L}^{-1}$ oleuropein reduced the rate of formation and the amount of methane produced was decreased. The ortho-diphenols (caffeic and protocatechuic acids) were inhibitory at $1000 \mathrm{mg} \mathrm{L}^{-1}$. Inhibition of methane production was evident when tyrosol was present at concentrations higher than $2000 \mathrm{mg} \mathrm{L}^{-1}$. In similar experiments, $p$-hydroxybenzoic acid enhanced methane production at levels of $500 \mathrm{mg} \mathrm{L}^{-1}$ and no enhancement or inhibition was observed at $700 \mathrm{mg} \mathrm{L}^{-1}$, but inhibition was noted when $p$-hydroxybenzoic acid was present at $1000 \mathrm{mg} \mathrm{L}^{-1}$.

In another research, washwaters coming from the cleaning of olives in the olive oil mill were treated in a laboratory-scale hybrid anaerobic reactor. The bottom third of the reactor was occupied by a sludge blanket, the upper two-thirds by submerged clay rings. This reactor was operated under mesophilic conditions at different influent substrate concentrations. The hydraulic retention times ranged from 0.2 to 1.02 days under normal operating conditions after the startup. COD removal efficiencies of more than $89 \%$ were achieved at an organic loading rate of $8 \mathrm{~kg} \mathrm{~m}^{-3} \mathrm{~d}^{-1}$. The system can tolerate COD loading rates as high as $17.8 \mathrm{~kg} \mathrm{~m}^{-3} \mathrm{~d}^{-1}$, with an average COD removal efficiency of $76.2 \%$ although the reactor was fed by a diluted influent having an average COD of $1030 \mathrm{mg} \mathrm{L}^{-1}$ at high hydraulic retention times $(\mathrm{HRT}=4.8 \mathrm{~h}) .^{17}$

In another study, $\frac{18}{}$ wastewater consisting of a high-strength palm oil mill effluent similar to olive oil mill wastewater was treated under mesophilic conditions by using a hybrid anaerobic digester as described earlier, having PVC rings filling the upper one-third of its volume. The influent COD concentration varied considerably $\left(11.6-65.0 \mathrm{~g} \mathrm{~L}^{-1}\right)$. The digester was fed with quantitative increases in COD loading rates between 3.3 and $18.6 \mathrm{~kg} \mathrm{~m}^{-3} \mathrm{~d}^{-1}$ at a set hydraulic retention time of 3.5 days. Results showed that the anaerobic digestion process is feasible for the treatment of palm oil mill effluent, and $92.3 \%$ COD removal efficiency and $0.335 \mathrm{~m}^{3} \mathrm{~kg}^{-1}$ methane yield could be achieved at COD loading of $16.2 \mathrm{~kg} \mathrm{~m}^{-3} \mathrm{~d}^{-1}$.

Another study was performed with an anaerobic hybrid reactor at a COD loading rate of $24 \mathrm{~kg} \mathrm{~m}^{-3} \mathrm{~d}^{-1}$ by using settled olive mill wastewater. Soluble COD removal efficiency and methane gas percentage of total produced biogas were $61.7 \%$ and $78.5 \%$, respectively. ${ }^{64}$ Anaerobic lagoons have been used for holding the olive oil mill wastewaters for pollution control and subsequent use as fertilizer after solar drying. These lagoons may serve organic load equalization during the whole year before treatment by other processes, too. Removals ranging between 30 and $80 \%$ were obtained after $2-4$ months. ${ }^{58}$ Anaerobic lagooning can be considered as an easy treatment method especially in warm climate areas, which is the case in the Mediterranean region. Thus, transporting the wastewaters produced from small olive oil plants into an anaerobic lagoon may be a feasible solution to the problem. However, permeation from the bottom of the lagoons must be prevented for soil and groundwater protection. Certain meteorological factors in the area, such as the wind direction and speed, should also be taken into consideration in order to minimize other environmental impacts due to methane and other odorous gas releases. This is especially important if there are settlement areas downwind of the lagoons. The most important advantage of anaerobic systems is biogas production, which may be used for energy production, although this requires additional investigations in order 
to evaluate its feasibility. Figure 2 shows two different alternative treatment schemes basically with anaerobic followed by aerobic biological treatment and ultrafiltration as the membrane process.

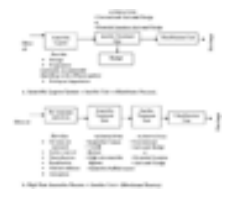

\section{FIGURE 2 Two treatment options with anaerobic followed by aerobic and membrane processes.}

[Medium View]

\section{[Enlarged View]}

The anaerobic baffled reactor (ABR) can also be applied for treatment of olive mill wastewaters. ABR consists of a series of baffled compartments where the wastewater flows upward through an anaerobic sludge bed. The ABR reactor does not require the sludge to granulate in order to perform effectively, although granulation does occur over time. ${ }^{63}$ This type of reactor was successfully applied to a wide range of wastewaters, such as from whisky distillery, molasses, piggery, slaughterhouse, pulp and paper, and icecream wastewaters, at laboratory-scale studies, and it was recommended for olive oil mill wastewaters, too. ${ }^{69}$ The ABR has many potential advantages, such as stability under hydraulic shock loadings, less sludge generation, and low capital and operating costs, coupled with mechanical simplicity. Due to different compartments in the reactor, adding an aerated stage in the last compartment in order to oxidize some of the remaining refractory COD and excess sulfide from the anaerobic stages can modify the reactor. This also enables nitrification, especially if immobilized cells are used. Due to the high sludge ages, the overall cell yields are $0.03 \mathrm{~g}$ cells $/ \mathrm{g}$ substrate, and hence little amount of sludge will be generated for disposal. Another useful feature of the ABR is its capability to treat wastewaters with high removal efficiencies (90-95\%) at low retention times $(10-20 \mathrm{~h})$.

In conclusion, high-rate anaerobic processes such as anaerobic filter or up-flow anaerobic sludge blanket reactors can be used to treat olive mill wastewaters containing 10-20 g L $\mathrm{g}^{-1} \mathrm{COD}$. Conventional anaerobic contact reactors can be used at higher COD concentrations up to $60 \mathrm{~g} \mathrm{~L}^{-1}$ with more than $80 \%$ COD removal efficiencies. However, when anaerobic processes are used for treatment of olive mill wastewaters, pretreatment is necessary.

\subsubsection{PRETREATMENT OPTIONS}

Pretreatment of olive mill wastewaters may be necessary as a first step before applying different treatment methods. Wastewater properties such as $\mathrm{pH}$, buffer capacity, nutrient content, toxicity, etc. must be adjusted before anaerobic digestion. Depending on the quantities and properties of solids in the wastewater, pretreatment operations that may be necessary are:

- Flotation, gravity settling, or membrane filtration.

- Physical or chemical pretreatment.

- Phase separation.

To get rid of the inhibiting substances, such as oils and polyphenols, physicochemical treatment methods should be applied. Neutralization is an essential pretreatment method before anaerobic units, as the methane formation is only possible at the $\mathrm{pH}$ range of 6.5-7.6. Olive mill wastewaters should be neutralized by using lime, sodium hydroxide, sodium carbonate, or bicarbonate. Ultrafiltration is a pretreatment method as mentioned earlier, as it reduces the biodegradable COD and allows very high removal of lipids and polyphenols in olive mill wastewaters. Centrifugation is more preferable than sedimentation, as it produces smaller volumes of the separated phase.

Significantly good results of removal of oil, COD, and phenolics were obtained in a study by adding $20-25 \mathrm{~g}$ $\mathrm{L}^{-1} \mathrm{Ca}(\mathrm{OH})_{2}$ to cause high $\mathrm{pH}$ values up to 12 . Using lime treatment, total solids were removed by $30-55 \%$, volatile solids by $30-65 \%$, oil and grease by $90-98 \%$, polyphenols by $65-76 \%$, volatile phenols by $30-46 \%$, and COD by $32-60 \% .^{-}$After lime application and removal of the fatty layer formed from the surface, the olive mill wastewater was more easily evaporating. It was shown that $o$-diphenols, which are the most phytotoxic components of phenolic materials in olive mill wastewaters, could be removed by lime treatment to render the treated wastewaters more easily biodegradable. ${ }^{1}$ In an ongoing research by Sengul, similar results were noted by adding bentonite up to $15 \mathrm{~g} \mathrm{~L}^{-1}$. It was cited that the biodegradable matter adsorbed on the surface of bentonite was gradually released during the bio-treatability test, thus allowing the same methane yields both in scarcely diluted (1/1.5) pretreated olive mill wastewater and in very diluted (1/12) untreated olive mill wastewater. ${ }^{10}, \underline{11}$ In both methods the resulting wastewaters were sent to biological treatment. 
Fenton's reagent based on ferric iron and hydrogen peroxide under acidic conditions at a $\mathrm{pH}$ range of 2.5-3.0

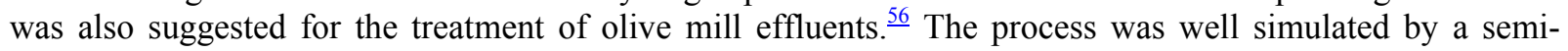
empirical reaction mechanism involving Fenton chemistry. The presence of oxygen due to simultaneous decomposition of hydrogen peroxide in water was believed to play an important role in the process. Fenton's reagent is quite efficient for phenol removal and can be considered as an efficient pretreatment step before applying a biological process to olive oil mill wastewater.

Equalization is one of the most important pretreatment options that are applied in full-scale operations to homogenize physical (flow, temperature, etc.) and chemical ( $\mathrm{pH}$, nutrients, organic material, toxic materials, etc.) parameters. ${ }^{41}$

\subsubsection{OTHER METHODS}

Various methods involving detoxification and beneficiation have been tested for full or partial treatment of olive mill wastewaters. For example, in a study ${ }^{62}$ the yeast Yarrowia lipolytica ATCC 20255 has been used for the treatment of olive oil mill wastewater. The results showed that the yeast was capable of reducing the COD by $80 \%$ in $24 \mathrm{~h}$, and $22.45 \mathrm{~g} \mathrm{~L}^{-1}$ biomass and enzyme lipase were obtained in a fermentation reactor. During this process, oil and grease, phenol, and carbohydrates were removed. Enzymatic removal of lowmolecular-weight phenolics and use of purified microbial polyphenol-oxidase (Trametes versicolor laccase) were tested in another study for phenol removal from olive oil wastewaters. $\frac{33}{}$ Although both enzymatic systems had relevant activities toward phenol polymerization, olive husk is more appealing than olive mill wastewater in view of possible applications. This is because of its vast availability at low cost in olive oil mills, as well as good enzymatic activity and specificity.

\subsubsection{USE OF OLIVE MILL WASTEWATER AS RAW MATERIAL IN ANTIOXIDANTS PRODUCTION}

Several compounds acting as natural antibacterial agents in olive fruit appear as significant components in the wastewater after olive oil production. Although they are presently discarded with the wastes, it is anticipated that these natural antioxidants have high economic value as they can be extracted from the wastes and used as

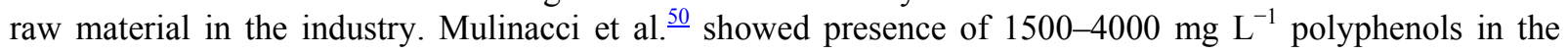
wastewaters coming from oil mills in Italy which can be used for antioxidants production. 


\section{ECONOMIC EVALUATION OF WASTEWATER MANAGEMENT OPTIONS IN OLIVE OIL INDUSTRY}

An advisable unique treatment alternative for economic treatment of olive mill effluents has not been suggested, yet. Currently the olive mill wastewaters are either impounded in storage lagoons or discharged into receiving media after insufficient treatment. Use of this wastewater for agricultural purposes is considered in some countries, but this is not a widely accepted method because of several important constraints. These constraints include the difficulty in finding large storage area to keep them until the irrigation season and sufficient field areas for irrigation. Scientific background to support safe agricultural use prior to treatment is not available. Impoundments and irrigation practices in general must also be critically studied in view of environmental releases of chemicals in the form of volatilizing substances into the air, infiltration into aquifers, or catastrophic events such as floods, equipment malfunction, or structural failure. ${ }^{42}$

Composition of the raw wastewater is important in determining the applicability of biological treatment methods. Biological treatment needs careful attention, costly pretreatment, and especially the anaerobic treatment methods require expert care. Sludge management is a particularly important issue after treatment. These practical problems as well as low efficiencies increase the unit cost of treatment and create difficulty in disposal. Determination of a minimum scale of operation to assure a smooth and feasible operation for olive oil mill wastewater treatment is not possible with the present level of field experience. This is an important issue as olive oil mills are sometimes very small plants working during 3-4 months of the year.

\subsection{Analysis of Unit Costs for Different Treatment and Disposal Alternatives}

In this part of the study costs were derived for different alternative treatment schemes (Table 6$)$. Because of the problems mentioned in treating olive oil mill wastewaters, there are not many full-scale treatment plants from which economic data could be obtained and pilot-plant data are used in deriving the costs involved. In some olive oil mills, centrifuging of the wastewaters is integrated in the production method for oil economy. In this process the amount of pollutants is decreased by $30-40 \%$. Although this is a good pretreatment alternative, wastewater centrifugation is not foreseen in this discussion in order to bring all methods to the same level for comparison in Table 6.

TABLE 6 Costs Due to Various Treatment Schemes for a Three-Phase Olive Oil Mill Generating $5000 \mathrm{~m}^{3}$ per Year Wastewater with 10 Years of Useful Life for the Treatment Units, Assuming 1:5

Oil to Wastewater Weight Ratio

\section{Treatment scheme*}

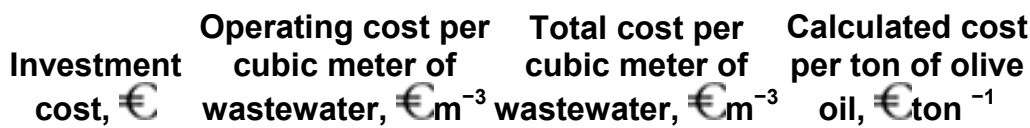

*Details of the treatment schemes 1-9 above are mentioned and corresponding cost data are taken from literature..$^{26}$ Alternative 10 is applied in Crete, Greece, and corresponding cost data are taken from reference 4 . Scheme 11 is a commercial evaporator unit of $288 \mathrm{~m}^{3} \mathrm{~d}^{-1}$ capacity, and cost of power is calculated by using the data in the company catalogue and cost of electricity in Turkey in 2000 .

$\begin{array}{lllll}\text { 1. Forced mechanical evaporation } & 180,700 & 6.82 & 10.43 & 52.1\end{array}$

+ lagooning

2. Physicochemical + biological $+\quad 150,600$

$8.68 \quad 11.69$

58.4

ultrafiltration

3. Biological (both solid wastes

180,700

6.21

9.82

49.1 and wastewater treatment)

4. Physicochemical + reverse

138,600 


\begin{tabular}{|c|c|c|c|c|}
\hline $\begin{array}{l}\text { 5. Physicochemical + } \\
\text { ultrafiltration }\end{array}$ & 216,900 & Not known & - & - \\
\hline $\begin{array}{l}\text { 6. Biological (anaerobic }+ \text { aerobic) } \\
+ \text { reverse osmosis }\end{array}$ & 180,700 & Not known & - & - \\
\hline 7. Vacuum evaporation & 96,400 & 3.69 & 5.62 & 28.1 \\
\hline 8. Forced natural evaporation & 42,200 & 0.47 & 1.31 & 1.5 \\
\hline 9. Improved natural evaporation & 30,100 & 0.05 & 0.65 & 3.2 \\
\hline $\begin{array}{l}\text { 10. Mechanical biological } \\
\text { pretreatment (biogas production) }+ \\
\text { sludge management (aerobic } \\
\text { stabilization }+ \text { solar drying) }\end{array}$ & $\begin{array}{c}500,000- \\
850,000\end{array}$ & $3.5-5.5$ & $13.5-22.5$ & $67.5-112.5$ \\
\hline 11. Commercial evaporator & 850,000 & 1 & 3.95 & 19.7 \\
\hline
\end{tabular}

Total costs of treatment on the basis of $1 \mathrm{~m}^{3}$ of wastewater (column 4) and 1 ton of olive oil produced (column 5) for different olive oil mill wastewater treatment schemes are given in Table 6. Data applies to $5000-\mathrm{m}^{3}$ per year wastewater generating facilities during a 100-day campaign with 10 years of useful life. In alternative scheme 11 , the commercial evaporator has a capacity of $288 \mathrm{~m}^{3}$ per day, which means that it can serve more than 5 mills of the size of mills in alternatives 1-10. The costs include the capital investment (column 2) and operating and maintenance (column 3) costs only.

At the end of the 10-year life period, $50,000 \mathrm{~m}^{3}$ would have been treated, and present value of the operating costs was calculated by assuming an interest rate of $2 \%$. The costs in column 4 were calculated by first adding investment and total operating costs for the 10-year lifetime and then dividing the results by $50,000 \mathrm{~m}^{3}$. To convert wastewater treatment unit costs in column 4 to costs per ton oil (column 5), a wastewater-to-oil weight ratio of 1:5 has been used in parallel with the data given in Table 2. All treatment units discharge treated waters with COD of about $4 \mathrm{~g} \mathrm{~L}^{-1}$.

Costs to be incurred on the olive oil product are in the order of 0.15 to 0.32 Euro-cents per kilogram oil for natural evaporation (schemes 8 and 9) and 1.9-11.2 Euro-cents per kilogram oil for the remaining more sophisticated treatment options. The cheapest scheme among the second category is evaporation-distillation of the wastewater (scheme 11); however, it should be noted that this alternative is for a $28,800-\mathrm{m}^{3}$ per year facility and not for a $5000-\mathrm{m}^{3}$ per year capacity facility. It is anticipated that smaller evaporator units for the same size as the other alternatives would create higher unit costs of treatment. In any case, even the highly sophisticated alternative of mechanical/biological treatment followed by anaerobic process with biogas production and full sludge management as applied in Crete ${ }^{4}$ would require 6-11 Euro-cents per kilogram oil under the circumstances described in this discussion. Unit cost of treatment per liter of oil is given as 3-6 Euro-cents in reference ${ }^{4}$. The difference is possibly due to different oil-to-wastewater ratios used in calculation, which may vary largely in practice.

From Table 6 it can be seen that natural evaporation both in forced or improved forms is the cheapest solution. In order to test these costs further, a simple calculation based on equipment consisting of a boiling tank can be considered. Investment cost of the boiler is negligible compared to what was discussed in Table 6 . Assuming an evaporator of $50 \%$ conversion efficiency is used and the theoretical heat required for evaporation is supplied by an electrical heater, operating cost is found as $135 €_{\mathrm{m}^{-3}}$. Alternatively, unit cost would be $32 €_{\mathrm{m}^{-3}}$ if natural gas was used as the energy source. These costs are based on the energy prices in Turkey in January 2000. Even such high figures due to boiling-evaporation using expensive heat sources are comparable with the figures in column 4 of Table 6. Using electrical heaters for evaporation of the wastewaters would increase the oil prices by 16 Euro-cents per kilogram only.

Another advantage of evaporation either in simple open pans or in high-technology evaporators is the potential benefits from reuse of the water to be condensed. It is known that the distilled water obtained from olive oil mill evaporators contains high COD. This water could be sent to domestic wastewater treatment 
plants for polishing operations if it complies with the connection regulations. Optionally, direct reuse of this condensed water would decrease the wastewater generation by at least $50 \%$. However, this practice is conditional as evaporation and condensation should be carried out on fresh wastewater to prevent agingrelated changes in its chemistry. Solids after evaporation can be handled as regular olive oil mill solid wastes.

Certain pretreatment methods may help evaporation and increase its efficiency and reduce the energy consumption. For example, centrifugal separation would be a good pretreatment step before evaporation. This step would bring two advantages; it would increase olive oil production in the mill, and the distillate from the evaporator would be cleaner. Use of other pretreatment alternatives such as chemical precipitation and filtration could make evaporation easier, too. Another pretreatment step before evaporation could be increasing the $\mathrm{pH}$ of olive mill wastewater. This keeps more of the volatile organic compounds in the solid fractions during evaporation, thus ending in lower COD in distillate. Elimination of volatile organic compounds from this distillate can be considered if it is feasible. This operation normally costs $5-6 \%$ of cost of evaporation but assures better distilled water quality for reuse. Alternatively, condensed water can also be reserved for fire-fighting when needed or for land irrigation. $\underline{\underline{39}}$

If the costs of treatment with natural evaporation alternatives (schemes 8 and 9 in column 1 of Table 6 ) are compared with traditional domestic wastewater treatment costs varying between 0.25 and 0.50 Euro-cent per cubic meter, they are rather close to this range. A cost correction based on corresponding COD loads of the domestic and olive oil mill wastewaters yields that traditional domestic wastewater treatment cost is more expensive on the unit COD load basis, as COD is $400 \mathrm{mg} \mathrm{L}^{-1}$ for domestic and $80,000 \mathrm{mg} \mathrm{L}^{-1}$ for olive oil mill wastewaters. In other words, domestic wastewater is 200 times more diluted than olive mill wastewaters, but is only 2-40 times less costly in treatment per unit volume.

It should be noted that COD could be reduced down to $4 \mathrm{~g} \mathrm{~L}^{-1}$ after treatment for the alternatives considered in Table 6. Therefore, effluents of the alternative schemes in Table 6 cannot be directly discharged into the environment. These effluents should be biologically treated for polishing and impounded for subsequent uses such as recycling or land irrigation. However, the decision should be made by taking into consideration the proximity of the activity to human settlements, as this method may have negative effects on the environment due to odorous volatile organic compound (VOC) emissions. 


\section{GASEOUS AND SOLID WASTES MANAGEMENT OPTIONS}

\subsection{Odorous Emissions}

Olive oil mills generate gas emissions resulting in significant odor complaints. Many of the volatile organic acids and other low-boiling organic substances create characteristic odors that can be detected around the olive oil mills. Uncovered storage lagoons and olive cakes with high moisture content are sources of odor nuisance, especially during warm and dry summer season. With increased trends of forced evaporation, distillation, or drying in higher technology units, treatment processes may create odor nuisance, too. Experimental data by the authors of this article indicate that condensed water from evaporation/distillation units still contains odorous organic fractions. Composition of gas emissions resulting from the solid waste storage and drying facilities, oil mill raw material silos, wastewater holding tanks, and evaporation and distillation units was not available in the literature.

Some ingredients of OMW, like fatty acids, have a characteristic irritating odor that may be recognized from long distances. Upon prolonged storage, seepage water also contributes to this odor unless a special drainage system is provided for olive solid wastes. Therefore, there may be a large number of complaints around olive mill solid waste burning facilities. On the other hand, the composition of the flue gases from solid waste combustion systems is well known. These are evaluated on the basis of combustion systems in the following section.

\subsection{Solid Waste Beneficiation and Disposal}

Olive oil mill solid wastes from presses and three-phase plants are often reclaimed by reprocessing in central plants. Solids are transported, dried, and extracted using hexane to reclaim the residual oils. Hexane is condensed and reused in these facilities. In some countries this extracted oil is a good starting material for the soap-stock manufacturing industry. Further refining and blending with high-quality "virgin" oils may result in good edible oils, provided the chemical composition is suitable. Due to direct contact with combustion gases at moderately high drying temperatures, the oil obtained from solid wastes by hexane extraction might contain incomplete combustion products such as polyaromatic hydrocarbons. This necessitates careful examination of the obtained residual oil before deciding if the material can be consumed as edible oil. To assure good quality, and for elimination of such residuals, filtering through activated carbon columns could be considered.

Many olive oil mills use dried and de-oiled residual solids as an alternative fuel source due to the high heating value of these wastes. The recovered heat can be used to help with the malaxation process in cold winter days. Sometimes the pits are separated from the vegetable parts in the solid wastes and either burned directly or used in manufacturing activated carbon. In Spain dried two-phase process solid wastes are used in cogeneration plants for power production but the energy costs are subsidized..$^{21}$ In some countries, like in Turkey, de-oiled solid wastes are considered as a good replacement for local low-quality lignite coals. Currently, de-oiled olive solid wastes in Turkey are partly burned in solid waste extraction plants to dry incoming olive solid wastes with high moisture content before extraction, and the remaining part is sold to other industries as an energy source. Emission studies carried out in the Marmara and Aegean regions of Turkey revealed that conventional combustion systems were used to burn the solid wastes, and stack gases do not comply with national air quality regulations. Although this material is a good renewable fuel, incomplete combustion resulting in high gaseous and particulate-phase hydrocarbons and carbon monoxide emissions is a significant problem. ${ }^{6}$ It is suggested that only dried and de-oiled olive solid wastes must be burned to achieve oil and energy economy and also to comply with stack gas emission regulations. .23 In Turkey, officials have recently permitted the use of olive oil mill solid wastes as "fuel" under certain conditions requiring changes in design of the boiler furnaces. These changes are in the research and development stage.

Solid wastes more than a few days old may create odor nuisance, more seepage water, and may develop increased acidity in the residual oil product, which makes the quality unsuitable for production of edible oil. Research indicates that to eliminate such problems olive solids must be extracted when they are fresh. Residual olive cakes after oil extraction can be utilized in furfural production or can be used as animal food additive and fertilizer. Also studies have shown that olive cake may be used as compost and is a good raw material in biotechnology.

Two-phase process wastes cannot be transported and dried easily, as the transport, storage, and drying machinery and equipment in residual oil recovery plants are not quite suitable. This means that a switch over from three-phase to two-phase oil production would force the waste oil recovery sector to go out of business. For solid wastes from two-phase production systems, composting is the recommended method of beneficiation, and co-composting of this wet material together with other agricultural wastes seems to be a reasonable approach before ultimate disposal. ${ }^{27}$ 


\subsection{Use of Olive Mill Solid Wastes in Combustion}

The solids remaining from residual oil extraction have better properties than other biomass or some local coals. This material has low sulfur content varying between 0.12 and $0.26 \%$. Lower heating value (LHV) of the dried solid wastes is in the range of $3922-4445 \mathrm{kCal} \mathrm{kg}^{-1}$. Proximate analyses of different parts of solid wastes from olive oil industries are given in Table $7 . \underline{22}$

TABLE 7 Proximate Analyses of Combustible Olive Wastes as Weight Percent on Dry Basis $\underline{6}$

Type of waste $\quad$ Moisture, $\% \quad$ Ash, $\% \quad$ Volatile matter, $\% \quad$ Fixed carbon, $\% \quad$ HHV, MJ kg ${ }^{-1}$

$\begin{array}{lccccc}\text { Olive cake } & 6.01-30.9 & 6.5-9.1 & 43.1-59.0 & 44.3-3.0 & 25.46-22.02 \\ \text { Olive stone } & 21.5 & 3.9 & - & - & 20.59 \\ \text { Olive seed } & 9.0-29.9 & 1.0-11.5 & 30\left(300^{\circ} \mathrm{C}\right) & - & -\end{array}$

In order to study the behavior of olive mill solid wastes during combustion as biomass fuel, reduction in mass with increasing temperatures was followed by preparing temperature-gravimetric analyses charts (TGA). This analysis revealed that after drying at $100^{\circ} \mathrm{C}$, this material loses its volatile fractions, and at $250-260^{\circ} \mathrm{C}$, original mass is reduced by $70-80 \% .^{-6}$ To burn them efficiently, a special boiler design with secondary air injection and high residence time in the primary combustion zone is required. Otherwise, significant levels of highly fluctuating concentrations of carbon monoxide and unburned hydrocarbons are emitted from conventional boilers designed for other fuels.

Another series of full-scale tests for the combustion of de-oiled olive cakes from Turkey was carried out in the Institute for Process Engineering and Power Plant Technology Department of Stuttgart University, Germany. Significance of several combustion parameters were examined using three different types of boiler $^{74}$ (Table 8). The combustion chamber of boiler number $1(150 \mathrm{~kW})$ consisted of two parts to realize staged combustion. Fuel is supplied with a screw feeder on a sloped grate into the primary combustion chamber, where the volatiles of the fuel are gasified. Final combustion occurred in the secondary combustion chamber, where a swirl fan provided good mixing of combustion gas and secondary air. Hot particle separation occurred in the vortex flow created by a cyclone located after the heat exchanger. Boiler number 2 $(150 \mathrm{~kW})$ has separate primary and secondary combustion chambers, hot gas circulation, and secondary zone had integrated hot particle separation using a swirl fan. Boiler number 3 was a common moving-grate furnace with a multicyclone after the heat exchanger for flue gas cleaning and had a thermal heat capacity of $240 \mathrm{~kW}$. Test results were based on 13\% excess oxygen in dry stack gases. By using a recording-type continuousemission test instrument, particulate matter $(\mathrm{PM})$, carbon monoxide $(\mathrm{CO})$, carbon dioxide $\left(\mathrm{CO}_{2}\right)$, nitrogen oxides $\left(\mathrm{NO}_{\mathrm{x}}\right)$, unburned hydrocarbons $\left(\mathrm{C}_{\mathrm{x}} \mathrm{H}_{\mathrm{y}}\right)$, and sulfur dioxide $\left(\mathrm{SO}_{2}\right)$ were measured. Table 9 summarizes emission results for carbon monoxide $(\mathrm{CO})$, nitrogen oxides $\left(\mathrm{NO}_{\mathrm{x}}\right)$ and particulate matter $(\mathrm{PM})$ from fullscale pilot combustion performance tests in grate-fired and rotary-type boiler furnaces. In the grate-fired units, secondary air was not provided and volatile fractions of the waste were released right after the introduction into the hot zone, where incomplete combustion products such as carbon monoxide (CO) were produced. In rotary units, $\mathrm{CO}, \mathrm{NO}_{\mathrm{x}}$, and $\mathrm{PM}$ emissions were lower than in fixed-grate units; however, air quality compliance could not be obtained. In both types of boilers $\mathrm{CO}$ emissions could be controlled only after secondary air was introduced to complete the combustion process. It was noted during the tests that the size distribution of the olive oil mill solid wastes was important for good combustion. Normally the percentage of fines with less than $3 \mathrm{~mm}$ size is above $50 \%$. When firing in grate-type units, small particles fall down and burn with less available oxygen under the grate to create much $\mathrm{CO}$ and unburned hydrocarbons. After cold start of combustion with high $\mathrm{CO}$ emissions, at optimized fuel feeding rates and air input ratios, incomplete combustion product emissions were reduced in further tests with boiler number 1.

TABLE 8 Half-Hour Mean Emission Concentrations of Combustion of De-Oiled Olive Mill Solid Wastes Based on 13\% Excess Oxygen Using Three Different Firing Systems in Continuous Operation Mode (Adapted from Reference ${ }^{74}$ )

Boiler number and capacity
Load, kW
Carbon monoxide, $\mathrm{mg}$ Nitrogen oxides, $\mathrm{mg}$ Particulate matter, $\mathrm{mg}$ $\mathrm{Nm}^{-3}$
$\mathrm{Nm}^{-3}$
$\mathrm{Nm}^{-3}$ 


$\begin{array}{lcccr}1(150 \mathrm{~kW}) & 69 & 93 & 313 & 157 \\ 2(150 \mathrm{~kW}) & 113 & 101 & 256 & 83 \\ 3(240 \mathrm{~kW}) & 214 & 18 & 297 & 162\end{array}$

TABLE 9 Emission Test Results ${ }^{7}$ in Ordinary Fixed- and Rotary-Grate Combustion Systems Without Secondary Air

$\begin{array}{llll}\text { Parameter Units } & \text { Fixed-grate furnace } & \text { Rotary-grate furnace }\end{array}$

Note. $\mathrm{Nm}^{-3}$ means per cubic meter of stack gas under 1 atm and $0^{\circ} \mathrm{C}$.

Stack gas temperature

Oxygen

Carbon monoxide

Nitrogen Oxides

Particulate matter

Sulfur dioxide
${ }^{\circ} \mathrm{C}$

$\%$

$\mathrm{mg} \mathrm{Nm}{ }^{-3}$

$\operatorname{mg~Nm}{ }^{-3}$

$\mathrm{mg} \mathrm{Nm}{ }^{-3}$

$\mathrm{mg} \mathrm{Nm}^{-3}$
139

11

8943

402

521

Not detectable
11

3445

261

273

Not detectable

Total airflow rates, as well as the primary and secondary air ratios, were found to be the important factors in minimizing the CO emissions. Under stabilized conditions of combustion, $\mathrm{CO}$ concentrations of less than 50 $\mathrm{mg} \mathrm{m}^{-3}$ and total unburned hydrocarbon concentrations of less than $20 \mathrm{mg} \mathrm{m}^{-3}$ were obtained. ${ }^{7}$ Primary and secondary air ratios, retention times, and temperature distribution are important design parameters for successful combustion. The lack of harmony among these parameters results in poor combustion of olive solid wastes, ending in high pollutant emissions. The combustion tests mentioned in reference 7 demonstrated that olive cake after chemical extraction may comply with the $250 \mathrm{mg} \mathrm{m}^{-3} \mathrm{CO}$ emission limit set by the Turkish air pollution legislation, $\frac{66}{}$ provided the combustion conditions set by the design of the furnace is suitable. Use of olive oil mill solid wastes as alternative renewable fuel source may lead the economy to benefit from a biofuel with almost no sulfur dioxide and little particulate matter stack gas emissions if properly burned. ${ }^{7}$ Combustion of biogas obtained from anaerobic digestion of the solid wastes in suitable reactors is also beneficial.

Co-combustion of olive mill solid wastes and coals in fluidized-bed combustors has been investigated in fullscale units. ${ }^{54}$ When fluidized-bed combustion is used for burning olive solid wastes, high moisture content has a negative impact on combustion efficiency and high $\mathrm{CO}$ emissions are noted. When the material is laid in a warm room for 1 day to be dried, incomplete combustion products are reduced in the fluidized-bed stack gases. Also, as fluidization properties have strong impacts on gas formation and completion of combustion, the secondary air introduction is expected to provide better combustion in fluidized-bed systems. ${ }^{6}$ Other methods of evaluation of olive mill solid wastes in energy production can be considered, too.

From the TGA charts it can be seen that immediate release of high masses of gases at a narrow temperature band of $250-260^{\circ} \mathrm{C}$ makes this material quite suitable to gasification. A modification of the combustion furnaces by adding a pregasification stage may extend the retention time in the hot zone and increase 
combustion efficiency. Still another option is to redesign or modify fluidized-bed reactors for burning olive oil mill solid wastes. 


\section{OLIVE MILL WASTE MANAGEMENT PRACTICES}

The majority of the olive and olive oil production in the Mediterranean region is carried out in Spain, Italy, Greece, and Turkey. Therefore, current practices for olive mill waste management in these countries are briefly discussed.

\subsection{Spain}

In 1981 the Spanish government prohibited the discharge of olive oil mill wastewaters into the receiving media and subsidized construction of storage ponds to promote evaporation during the summer period. Around 1000 evaporation ponds were constructed, which improved the water quality, but raised annoyances in ambient air quality because of odor problems. More recently, two-phase oil mills replaced traditional production techniques in Spain.

\subsection{Italy}

As a consequence of water pollution control legislation in Italy, olive mill wastewaters had to undergo treatment before their release into the environment. Several provisory legislative and ministerial decrees were promulgated to permit wastewater spreading on land, at least under controlled conditions, due to the difficulties of complying with these discharge standards. In view of the high cost of treatment plants and taking into account the potential economic and social problems that may originate from olive oil industry, this special legislation was promulgated.

Taking into account the results of studies performed especially in Spain and Italy that demonstrated the high fertilizing value of olive oil wastewaters, the possibility of using them as soil conditioners was permitted. To this end a regulation about olive waste disposal and/or recycling was promulgated. This new regulation allowing the reuse of olive mill wastewaters in agriculture is now the only state regulation in force regarding olive mill wastewaters and permits use of wet solid waste from the two-phase process as fertilizers on croplands. Such spreading on land must be communicated to the local authority and supported by a technical report.

\subsection{Greece}

At present, European regulation is in force, although some local administrations are imposing stricter environmental requirements.

In Greece, small olive mills serving local communities are widespread, especially in low-income areas. Wastewaters are usually collected in impoundments in such areas. Extensive research is underway in the research organizations and universities in order to safely dispose of this water within 3 months after the campaigns.

\subsection{Turkey}

Turkish Water Pollution Control Regulation ${ }^{67}$ oversees protection of the water resources against pollution and sets discharge standards both for protection of the receiving media and for effluents of olive oil mills. There is no specific regulation regarding the discharge of olive mill wastewaters. It appears that Turkish olive oil producer will experience a crisis similar to other European countries, if an economically viable and environmentally friendly solution is not found to dispose the wastes. Local administrations are deeply concerned with the problems, as municipal wastewater plants are usually not designed to accept such highstrength wastewaters, and they must solve the nuisances before tourism season begins each year.

Even though the Turkish olive producers choose defensive behavior and claim that there is no significant environmental impact caused by olive oil sector, of course that is not the case. The biggest and main obstruction in front of the safe disposal of olive oil mill wastewater is the fact that enterprises are small and scattered in a large geographical area.

In regard to solid wastes resulting from olive oil production, the Ministry of Environment in Turkey has permitted the combustion of dried solid cake only in olive oil mills beginning with 2003, with the condition that the emission limits are met. 


\section{DISCUSSION}

\subsection{Strategies of Handling Olive Oil Wastes}

Different waste management approaches for olive and related industry wastes must exist in olive and olive oil producing countries. These strategies are shaped by irrigation and soil-conditioning requirements, composting practices, wastewater discharge regulations, public complaints due to odor and fly nuisances, impacts on tourism, and proximity to recreation and settlement areas. Biannual capacity changes and seasonal campaigns of olive harvesting between November and March are important aspects in these strategies, too.

It should be noted that waste management in olive mill production is a tough problem, and its optimum solution must foresee local factors to be taken into account. Among them are the type of oil extraction process in use, the possibility of handling and storing the wastes, the volume of the wastes, and land availability.

More modern approaches aiming at cleaner production technologies take into account not only the olive and olive oil economies, but also the potential beneficial use of olive mill wastes. In some other approaches, OMW is considered as resource and its certain constituents are valuable starting material for some industries such as antioxidants production. Relative abundance of water in the rainy winter period in the Mediterranean climate areas does not encourage the producers to apply water conservation techniques, but recycling of water must always be a consideration for economy of production. Especially if water is reclaimed and stored for future use in the dry summer period, that will certainly create positive impacts on local economies. Environmental impacts of auxiliary investments based on reclaimed material such as olive oil refineries, soapstock manufacturing plants, solid waste residue oil facilities, and biomass fuel combustion are also important considerations.

\subsection{Overview of Waste Treatment Options for Management Strategies}

The traditional end-of-pipe strategy considers OMW as a waste that has to go through complex physicochemical and biological treatment schemes before discharge into the receiving media. The selection of candidate treatment scheme is a function of olive oil production method, availability, and cost of land for potential storage and evaporation and the local climate. Proximity of the site to human settlements and geographical distribution of the mills are other practical considerations in waste management models to be adopted.

Constructing separate treatment plants for each facility is usually not an economic solution when smallcapacity olive oil mills predominate in a region, so a treatment plant located centrally may be constructed. However, local conditions may necessitate separate treatment plants in some cases. Centralized treatment plants usually require high transportation costs, although they are more efficient and economically more feasible than individual treatment facilities of smaller size. A collection system to gather the wastewaters into a large impoundment for storage, beneficiation, treatment, and reuse might be a good idea. ${ }^{49}$

For olive mills, compliance with water discharge regulations only by using a simple aerobic treatment is impossible because of the characteristics of the olive oil wastewater. However, biological treatment is possible when a combination of aerobic and anaerobic methods is applied, especially when it is diluted with municipal wastewater.

For the anaerobic treatment of olive oil mill wastewater, lagoons, digesters, contact reactors, filters, or UASB reactors can be used. If a central treatment plant is to be built to utilize anaerobic methods, various alternative strategies may be taken into consideration. However, it is highly recommended that pilot-scale studies should be carried out before designing anaerobic treatment units. Performance and feasibilities of the pilot plants should be evaluated with experimental data obtained at different hydraulic retention times and organic loading rates by using diluted or raw pretreated olive mill wastewater.

Chemical treatment by coagulation-flocculation is neither simple nor efficient for the reduction of organic materials in the olive oil mill wastewaters. However, this process may be applied to the wastewater as a posttreatment to remove the suspended solids after biological units. After pretreatment with addition of lime, olive mill wastewaters can be evaporated and settled more easily. In this method, if lime is used in high quantities to bring wastewaters to $\mathrm{pH} \mathrm{12,} \mathrm{some} \mathrm{toxic} \mathrm{or} \mathrm{hard-to-degrade} \mathrm{constituents} \mathrm{of} \mathrm{the} \mathrm{olive} \mathrm{mill}$ wastewaters are eliminated and the remaining pollutants can be treated biologically after neutralization. As this process helps the phase separation, it may be used in discrete small mills to minimize the overall retention time during functional separation of oil, settleable solids, and water in three-stage wastewater treatment. It is also known that application of lime shortens the required retention time in settling lagoons. If a central collection and treatment facility is not feasible due to the distance between small mills, controlled irrigation may be considered after removal of oil and suspended matter. An extended storage period is necessary in the Mediterranean climate, as irrigation may begin 4-6 months after the wastewater is produced. Also, a thorough 
examination of the water before irrigation is absolutely necessary. Sludge resulting from storage in lagoons can be either composted or mixed with olive mill solids wastes before disposal or other operations and uses.

Membrane processes are also tested for use in treatment of olive oil mill wastewaters. Ultrafiltration is the widely considered membrane process for this purpose. In these processes two different phases are obtained: retentate (concentrate) and permeate. Permeate is sent to wastewater treatment plants for posttreatment and is usually reused. The retentate can be added to municipal solid wastes and disposed of in landfill areas or can be composted with solid wastes. When wastewater from an olive oil mill must be discharged into sensitive environmental media, a combination of anaerobic pretreatment followed by ultrafiltration and reverse osmosis is recommendable. Research continues for oxidizing the olive mill wastewaters with electrochemical or photochemical processes or by the help of peroxide or Fenton reactions as described earlier.

Thermal treatment contains evaporation and distillation processes, either by solar energy (natural evaporation) or by using electricity or natural gas firing. This is the only group of alternative methods that can be defended on economic grounds. This kind of treatment requires storage of the olive mill wastewaters produced during the wet winter season. On the other hand, forced-air evaporation allows concentrating of the wastewater by injecting it into the air to improve evaporation (Table 6, scheme number 8). Alternatively to increase the evaporation surface special gratings are sometimes installed to the ponds (Table 6, scheme number 9).

Olive mill solid wastes must be processed to recover the residual oils they contain. Recovered oil from olive mill solid wastes may be used in soap-stock manufacturing, or if the quality allows it can be blended with high-quality oils and sold as edible oil. De-oiled solids may be composted together with other agricultural wastes, or used as biomass fuel or raw material for biotechnology.

Industry for manufacturing enzymes or other biotechnological products may use olive oil mill wastes as raw material. Composting of two-phase olive oil mill wastes is possible usually in combination with other agricultural wastes. In Spain a composting study of these wastes with solid materials such as cereal straws, press extracted olive cake, sorghum and sugar cane bagasses, or cotton wastes has been developed and useful organic fertilizers have been obtained. ${ }^{21}$

\subsection{Other Beneficial Uses of Olive Oil Wastes}

As mentioned earlier, olive mill wastes can be considered as resources to be recovered. But of course, promotion of valuable by-product recoveries at olive oil mills can only be achieved depending on the market demand. The potential recoverable by-products are livestock feed (single-cell protein), biogas production, enzyme production, and production of mushrooms.

Stones from milling or de-oiled solid wastes are used as fuel in power plants. It is known that there are industrial power plants that have successfully been working, and several others are under construction. Composting, on the other hand, may also develop a capacity for handling other wastes, as olive oil mill wastes are produced seasonally. Biotechnology or biological treatment after mixing with other agricultural wastes is also possible after adding nitrogen into the olive oil mill wastes. In the case of anaerobic treatment, biogas production is possible, and this may enable electricity production. 


\section{CONCLUSIONS}

The technical, economic, and legislative aspects of environmental problems resulting from olive oil production industries have been discussed and following conclusions can be drawn:

- Countries must have strong governmental policies regarding olive mill wastes, taking into account the economic role of this sector at small villages in remote areas, and at large premises at the same time. In this model, de-oiling facilities of the olive solids and subsequent fuel production sector should not be ignored. Also, the strategies of olive plantations and agriculture should be taken into consideration. This requires an integrated approach in the waste management operations of olive sector, with provisions made for the farmers, industries, energy, water resources, and regulatory bodies.

- Environmental issues should be considered in choosing, developing, and using of olive oil production methods. Cleaner production methods should be developed and adopted whenever possible.

- Switching from press and three-phase to two-phase production methods creates demand for new, environmentally sound and economically viable solutions for waste treatment and disposal. Two-phase technologies result in a watery olive cake, which is not necessarily easier to treat and dispose of safely. Therefore, although less water is used compared to the three-phase process, two-phase processes do not completely eliminate the environmental problems.

- A simple method of end-of-pipe treatment is not known for olive oil mill wastewaters. Biological treatment is not cheap method for the treatment of olive mill wastewaters. Besides, it is doubtful that the effluent from even successive biological treatment steps such as anaerobic and aerobic would comply with the environmentally acceptable discharge criteria. Also, there are other disadvantages inherent in biological treatment system selection:

a. Anaerobic treatment for olive mill wastewaters needs expert care. On the other hand, sludge problems of aerobic treatment plant cannot be neglected.

b. The volume of excess sludge produced is high, as incoming wastewaters have high solids content. In conclusion, the biological treatment of olive mill wastewaters should be considered only after careful examination of feasibility and practicability.

- Treatment of olive oil mill wastes is difficult if not totally impossible in many cases. It can be advised that small-scale, remote olive oil mills keep the wastewater volumes of 3-to 5-month campaign periods in large enough basins. Alternatively, wastewaters can be transported to a central treatment plant via separate sewer systems or tankers, provided large-scale treatment in central treatment units is more feasible.

- To prevent permanent pollution of receiving media and soils, direct land application of olive mill wastewaters with no regard to its acidic, toxic, oily composition has to be avoided. This option requires utmost care before it can be permitted.

- A regulated solid-waste market must be established for recovery of residual oils. Such control would ensure that the residual oils would not be wasted upon burning in individual mills. Only the de-oiled solid wastes should be considered as a replacement fuel to be burned in properly designed or modified furnaces. Redesign or modification of existing combustion systems is usually necessary in order to allow compliance with air pollution control regulations.

- It was concluded that there are no miraculous solutions to the waste problems of olive oil industry. Proposed solutions must be environmentally friendly, economically viable and acceptable by all and it should not cause a social crisis. An acceptable management model for olive mill wastes has to be worked out by considering the following;

- Storage and transport of wastes produced during the campaign season.

- Careful economic feasibility and practicability of possible treatment schemes for the mills that are not suitable for central collection and treatment option 
- Evaluation of impoundments added by evaporation/distillation options and possibilities of reuse of treated waters after de-oiling and settling.

- Evaluation of burning the solid fraction resulting from olive mill solid wastes deoiling facilities.

- Evaluation of the possibilities for using liquid fraction as starting material for biotechnological methods.

The following additional remarks should be made for successful olive oil waste management strategies:

- Cleaner production techniques and technologies must be searched for in olive oil mills, to include water conservation by using evaporation/distillation followed by reuse of water, and energy conservation by way of safely burning the olive oil mill solid wastes or biogas material derived from them. These will create and increase the benefits from environmental and economic points of view.

- All olive oil producer countries are located in geographic areas where a vast amount of solar energy is available for cheap evaporation. Provided that odor and fly problems are prevented, solar evaporation can be the most practical one among other schemes.

In conclusion, olive oil mill wastes should be considered as economic resources that can be turned into valuable products in progressing toward a permanent solution to waste disposal problems. Feasible methods will have to be found and employed to solve the environmental problems to assure sustainability. 


\section{REFERENCES}

1. Aktas, E. S., Imre, S., and Ersoy, L. Characterization and lime treatment of olive mill wastewater. Water Res. 35, 9 2336-2340, (2001). [CROSSREF][PUBMED][INFOTRIEVE].

2. Anonymous Olive oil may reduce colorectal cancer risk. Environ. Nutr. 24, 1 8, (2001).

3. Annesini, M. C., and Gironi, F. Olive oil mill effluent: Ageing effects on evaporation behaviour. Water Res. 25, 1157, (1991).

4. AquatecOLIVIA, Schmidt, A., and Knobloch, M. Treatment and processing of residues from olive processing EU Life project. www.aquatec-engineering.com.

5. Aveni, A. Biogas recovery from olive-oil mill wastewater by anaerobic digestion. Anaerobic Digestion and Carbohydrate Hydrolysis of Waste pp. 489-491, (1984).

6. Bayram, A., and Dumanoglu, Y. Evaluation of prina as fuel [in Turkish]. Proc. First Int. Symp. Environmental Problems in Olive Oil Production and Solutions 7-9, (June 2002). N. Azbar, N. Vardar, M. Akin and I. Cevilan (eds.), Balikesir University, Balikesir, Turkey.

7. Bayram, A. Pirina as a renewable energy resource: The production, properties and evaluation [in Turkish]. Proc. Renewable Energy Sources Symposium Chamber of Electrical Engineers Izmir Branch, 18-20, (January 2001). pp. 108-112, Izmir.

8. Beccari, M., Bonemazzi, F., Majone, M., and Riccardi, C. Interaction between acidogenesis and methanogenesis in the anaerobic treatment of olive oil mill effluents. Water Res. 30, 183, (1996).

9. Beccari, M., Majone, M., and Torrisi, L. Two-reactor system with partial phase separation for anaerobic treatment of olive oil mill effluents. Water Sci. Technol. 38, 4-5 53-60, (1998).

10. Beccari, M., Majone, M., Riccardi, C., Savarese, F., and Torrisi, L. Integrated treatment of olive oil mill effluents: Effect of chemical and physical pretreatment on anaerobic treatability. Water Sci. Technol. 40, 1 347-355, (1999).

11. Beccari, M., Majone, M., Papini, M. P., and Torrisi, L. Enhancement of anaerobic treatability of olive oil mill effluents by addition of $\mathrm{Ca}(\mathrm{OH})_{2}$ and bentonite without intermediate solid/liquid separation. Water Sci. Technol. 43, 11 275-282, (2001). [PUBMED][INFOTRIEVE].

12. Bisignano, G., Lagana, M. G., Trombetta, D., Arena, S., Nostro, A., Uccella, N., Mazzanti, G., and Saija, A. In vitro antibacterial activity of some aliphatic aldehydes from Olea europaea L. FEMS Microbiol. Lett. 198, 19, (2001). [CROSSREF][PUBMED][INFOTRIEVE].

13. Boari, G., Mancini, I. M., and Trulli, E. Anaerobic digestion of olive mill effluent pretreated and stored in municipal solid waste sanitary landfills. Water Sci. Technol. 28, 2 27, (1993).

14. Bonazzi, M. Euro-Mediterranean policies and olive oil: Competition or job sharing. Executive Summary. EUR 17270 EN Seville, (1996).

15. Borja, R., Martin, A., Alanso, V., Garcia, I., and Banks, C. J. Influence of different aerobic pretreatments on the kinetics of anaerobic digestion of olive mill wastewater. Water Res. 29, 2 489, (1995).

16. Borja, R., Banks, C. J., Maestro-Duran, R., and Alba, J. The effects of the most important phenolic constituents of olive mill wastewater on batch anaerobic methanogenesis. J. Environ. Technol. 17, 167174, (1996).

17. Borja, R., Alba, J., and Banks, C. J. Anaerobic digestion of wash waters derived from the purification of virgin olive oil using a hybrid reactor combining a filter and a sludge blanket. Process Biochem. 31, 3 219-224, (1996).

18. Borja, R., Banks, C. J., Khalfaoui, B., and Martin, A. Performance evaluation of an anaerobic hybrid digester treating palm oil mill effluent. J. Environ. Sci. Health A 31, 6 1379-1393, (1996).

19. Carrieri, C., Balice, V., and Rozzi, R. Comparison of three anaerobic treatment processes on olive mills effluents. Proc. Int. Conf. Environment Protection Italy, (1988).

20. Chakchouk, M., Hamdi, M., Foussard, J. N., and Debellefontaine, H. Complete treatment of olive mill wastewaters by a wet air oxidation process coupled with a biological step. Environ. Technol. 15, 4 323, (1994).

21. Cegarra, J., Alburquerque, J. A., Gonzalves, J., and Garcia, D. A survey of olive-mill wastes in Spain, feasibility of composting. Proc. First Int. Symp. Environmental Problems in Olive Oil Production and Solutions 7-9, (June 2002). N. Azbar, N. Vardar, M. Akin and I. Cevilan (eds.), Balkesir University, Balikesir, Turkey. 
22. Demicheli, M., and Bontoux, L. Survey current activity on the valorization of by-products from the olive oil industry. European Commission Joint Research Centre, Final Report. www.jrc.es/projects/ff/EC/IPTS/IPTSPUBL.html (1996).

23. Dumanoglu, Y. Investigation of pirina combustion in a test boiler for energy production. Unpublished MSc thesis Dokuz Eylul University, Graduate School of Natural and Applied Sciences, Izmir. (2003).

24. Duarte, E. A., and Neto, I. Evaporation phenomenon as a waste management technology. Water Sci. Technol. 33, 8 53, (1996).

25. Ergüder, T. H., Güven, E., and Demirer, G. N. Anaerobic treatment of OMW in batch reactors. Process Biochem. 36, 3 243-248, (2000).

26. FAIR CT96-1420, Annex 2 Final report, Improlive, investments of treatment and validation of liquidsolid waste from the two phase olive oil extraction www.nf-2000.org/publications/q30011.pdf (2000).

27. Filippi, C., Bedini, S., Levi-Minzi, R., Cardelli, R., and Saviozzi, A. Co-compositng of olive oil mill byproducts: Chemical and microbiological evaluations. Compost Sci. Utilization 10, 1 63-72, (2002).

28. Galili, E., and Sharvit, J. 20,000 Olives under the sea. Archaeol. Hist. Israel Discover 19, 5 16, (1998).

29. Georgacakis, D., and Dalis, D. Controlled anaerobic digestion of settled olive-oil wastewater. Bioresource Technol. 46, 221, (1993).

30. Gharsallah, N. Influence of dilution and phase separation on the anaerobic digestion of olive mill wastewaters. Bioprocess Eng. 10, 29, (1994).

31. Giannakas, K., Tran, K., and C. Efficiency, technological change and output growth in Greek olive growing farms: A Box-Cox approach. Appl. Econ. 32, 909, (2000).

32. Gonzalez, M. D., Moreno, E., Quevedo, J., and Ramos, A. Studies on antibacterial activity of waste waters from olive oil mills (alpechin): Inhibitory activity of phenolic and fatty acids. Chemosphere 20, 432, (1990).

33. Greco, Jr., G., Toscanoa, G., Cioffi, M., Gianfreda, L., and Sannino, F. Dephenolisation of olive mill wastewaters by olive husk. Water Res. 33, 3046, (1999).

34. Hamdi, M. Thermoacidic precipitation of darkly coloured polyphenols of olive mill wastewaters. Environ. Technol. 14, 495, (1993).

35. Hamdi, M. Future prospects and constraints of olive oil mill wastewaters use and treatment, a review. Bioprocess Eng. 8, 209, (1993).

36. Hamdi, M., Garcia, J. I., and Ellouz, R. Integrated biological process olive oil mill wastewater treatment. Bioprocess Eng. 8, 79, (1992).

37. Hamdi, M. Toxicity and biodegradability of olive mill wastewaters in batch anaerobic digestion. Appl. Biochem. Biotechnol. 37, 155, (1992).

38. Henderson, C. W. Olive oil may prevent development of bowel cancer. Cancer Weekly 23, (2000). [CROSSREF].

39. Improlive (2000). http://www.fiw.rwth-aachen.de/improlive/rsanfall/abwasser/anaerob.html.

40. Israilides, C. J., Vlyssides, A. G., Mourafeti, V. N., and Karvouni, G. Olive oil wastewater treatment with the use of an electrolysis system. Bioresource Technol. 61, 2 163, (1997).

41. Iza, J., Colleran, E., Paris, M. J., and Wu, W. M. International workshop on anaerobic treatment technology for municipal and industrial wastewaters: Summary papers. Water Sci. Technol. 24, 8 1-16, (1991).

42. Johnson, B., Balserak, P., Beaulieu, S., Cuthbertson, B., Steward, R., Truesdale, R., Whitmore, R., and Young, J. Industrial surface impoundments: Environmental settings, release and exposure potential and risk characterization. Sci. Total Environ. 317, 1-3 1-22, [CROSSREF][PUBMED][INFOTRIEVE].

43. Kasirga, E. Treatment of olive oil industry wastewaters by anaerobic stabilization method and development of kinetic model [in Turkish]. Unpublished PhD thesis Dokuz Eylul University, Graduate School of Natural and Applied Sciences, Izmir, Turkey. (1988).

44. LED Italia Olive mill water treatment through vacuum evaporation. Technical report 7, LED Italia s.r.l. (1997).

45. Longhi, P., Vodopivec, B., and Fiori, G. Electrochemical treatment of olive oil mill wastewater. Ann. Chim. 91, 3-4 169, (2001). [PUBMED][INFOTRIEVE]. 
46. Marques, I. P., Teixeira, A., Rodrigues, L., Martins Dias, S., and Novais, J. M. Anaerobic treatment of olive mill wastewater with digested piggery effluent. Water Res. 70, 5 1056, (1998).

47. Martin, J., and Moreno, M. The role of olive oil in lowering cancer risk: Is this real gold or simply pinchbeck. J. Epidemiol. Commun. Health 54, 10 721, (2000).

48. Masghouni, M., and Hassairi, M. Energy applications of olive oil industry by-products:-I. The exhaust foot cake. Biomass Bioenergy 18, 257-262, (2000).

49. Muezzinoglu, A., and Uslu, O. Alleviation of pollution due to olive oil production, some practical considerations from Turkey. International Symposium on Olive By-Products Valorization Food and Agriculture Organization of the United Nations, Seville. pp. 159-168, (1986).

50. Mulinacci, N., Romani, A., Galardi, C., Pinelli, P., Giaccherini, C., and Vincieri, F. F. Polyphenolic content in olive oil wastewaters and related olive samples. J. Agric. Food Chem. 49, 8 3509, (2001). [CROSSREF][PUBMED][INFOTRIEVE].

51. Nychas, G. J.E., Tassou, C., and Board, R. G. Phenolic exctract from olives: Inhibition of Staphylococcus aures. Lett. Appl. Microbiol. 10, 217, (1990).

52. Newmark, H. L. Squalene, olive oil and cancer risk: A review and hypothesis. Cancer Epidemiol. Biomarkers Prevent. 6, 1101, (1997).

53. Oktav, E., and Sengul, F. A study on treatability of olive mill wastewaters [in Turkish]. ITU 7. Endustriyel Kirlenme Kontrolu Sempozyumu 2000 Proceedings of Industrial Pollution Symposium 2000 pp. 51-58, Istanbul Technical University, Istanbul. (2000).

54. Patumsawad, S., and Cliffe, K. R. Experimental study of fluidized bed combustion of high moisture municipal solid waste. Energy Combust. Manage. 43, 17 2329-2340, (2002).

55. Ranalli, A. Microbial treatment of oil mill waste waters. Grasas Acetes 43, 16, (1992).

56. Rivas, F. J., Beltrán, F. J., Gimeno, O., and Frades, J. Treatment of olive oil mill wastewater by Fenton's reagent. J. Agric. Food Chem. 49, 4 1873, (2001). [CROSSREF][PUBMED][INFOTRIEVE].

57. Rozzi, A., and Malpei, F. Treatment and disposal of olive mill effluents. Int. Biodeterior. Biodegrad. 38, 3-4 135, (1997).

58. Rozzi, A., Santori, M., and Spinosa, L. Anaerobic digestion in Italy with special reference to treatment of olive oil mill wastes. Anaerobic Digest. Sewage Sludge Org. Agric. Wastes 55-65, (1986).

59. Samsunlu, A., Tünay, O., Öztürk, Z., and Alp, K. Characterization and treatability of olive oil wastewaters (in Turkish), İ.T.Ü. 6. Industrial Pollution Symp. Proc. pp. 93-99, Istanbul, (1998).

60. Sengul, F. Industrial wastewater characteristics and treatment [in Turkish]. Faculty of Engineering Textbook Series Dokuz Eylul University Faculty of Engineering Press, Izmir. (1991).

61. Sengul, F., Oktav, E., and Cokay, E. Treatment of olive oil mill wastewaters and beneficiation of the byproducts [in Turkish]. 2000 GAP-Environment Congress Proc. Harran University, 2, 713, 16-18, (2000). Sanliurfa, Turkey.

62. Scioli, C., and Vollaro, L. The use of Yarowia lipolytica to reduce pollution in olive mill wastewaters. Water Res. 31, 10 2520, (1997).

63. Skiadas, I. V., and Lyberatos, G. The periodic anaerobic baffled reactor. Water Sci. Technol. 38, 8-9 401408, (1998).

64. Tsonis, S. P., and Grigoropoulos, S. G. Anaerobic treatability of olive oil mill wastewater. Water Sci. Technol. 28, 2 35, (1993).

65. Tuncel, G., and Nergiz, C. Antimicrobial effect of some olive phenols in a laboratory medium. Lett. Appl. Microbiol. 37, 155, (1993).

66. Turkish Air Pollution Control Regulation Official Gazette 19269, (2 November 1986).

67. Turkish Water Pollution Control Regulation Official Gazette 19919, (4 September 1988).

68. Ubay, B., and Ozturk, I. Anaerobic treatment of olive mill effluents. Water Sci. Technol. 36, 2-3 287 , (1997).

69. Uyanik, S. Process performance and bacterial population dynamics in conventional and modified anaerobic baffled reactors treating industrial wastewaters. Unpublished $\mathrm{PhD}$ thesis University of New Castle (2001).

70. Vlyssides, A. G., Loizides, M., and Karlis, P. K. Integrated strategic approach for reusing olive oil extraction by-products. J. Cleaner Prod. (in press). 
71. Wellman, T. Replenishing your immune system with nature's antibiotic apothecary. Total Health 23, 6 76, (2001).

72. Yesilada, O., Fiskin, K., and Yesilada, E. The use of white rot fungus Funallia trogii (Malatya) for the decolorization and phenol removal from olive mill wastewater. Environ. Technol. 16, 95, (1995).

73. Zouari, N., and Eloouz, R. Toxic effects of colored olive compounds on the anaerobic digestion of olive mill effluent in UASB-like reactors. J. Chem. Technol. Biotechnol. 66, 4 414, (1999).

74. Zuberbuehler, U., Berger, R., Baumbach, G., Hein, K. R.G., and Bayram, A. Combustion performance with residues of olive oil production in three different firing systems for decentralized process heat generation. 1st World Conf. Exhibition on Biomass for Energy and Industry 5-9, (June 2000). Sevilla, Spain, 8, 48. 


\title{
Taylor \& Francis
}

Article Title: A Review of Waste Management Options in Olive Oil Production

Journal Title: Critical Reviews in Environmental Science and Technology | Vol: 34 | Issue: 3 | Year: 2004 | PP: 20s

Print Article

Print ISSN: 1064-3389(Detailed Informa

Critical Reviews in Environmental Science and Technology

Publisher: Taylor \& Francis

Issue: Volume 34, Number 3 / May-June 2004

Pages: $209-247$

URL: Linking Options

DOI: $10.1080 / 10643380490279932$

A Review of Waste Management Options in Olive Oil Production

\author{
NURI AZBAR ${ }^{\mathrm{A} 1}$, ABDURRAHMAN BAYRAM ${ }^{\mathrm{A} 2}$, AYSE FILIBELI ${ }^{\mathrm{A} 2}$, AYSEN MUEZZINOGLU ${ }^{\mathrm{A} 2}$, \\ FUSUN SENGUL ${ }^{\mathrm{A} 2}$, ADEM OZER ${ }^{\mathrm{A} 2}$ \\ ${ }^{A 1}$ Department of Bioengineering, Ege University, Bornova, Izmir, Turkey \\ ${ }^{\text {A2 }}$ Department of Environmental Engineering, Dokuz Eylul University, Kaynaklar Campus, Buca, Izmir, \\ Turkey
}

\begin{abstract}
:
In this article, treatment and disposal alternatives of olive oil mill wastes and technical requirements for their management are covered. Waste characteristics, treatment options with regard to the economic feasibility, and challenges of existing waste disposal practices in olive growing countries are mentioned. Attention is drawn to present-day techniques of waste management. The search concerning the environmentally acceptable, economically feasible, and practically applicable methods of disposal of olive oil mill wastes is referred. In the management schemes, compliance with environmental regulations and economic and social benefits of the olive oil production are the goals that must be simultaneously achieved.
\end{abstract}

\section{Keywords:}

Mill Wastewaters, Olive Oil, Olive Wastes, Treatment Economy, Waste Combustion, Wastewater Treatment

\section{References:}

1. Aktas E. S., Imre S., Ersoy L.. Characterization and lime treatment of olive mill wastewater. Water Res.. 35; 9; 2336-2340. (2001): [CROSSREF][PUBMED][INFOTRIEVE]

2. Anonymous. Olive oil may reduce colorectal cancer risk. Environ. Nutr.. 24; 1; 8. (2001):

3. Annesini M. C., Gironi F.. Olive oil mill effluent: Ageing effects on evaporation behaviour. Water Res.. $25 ; 1157$. (1991):

4. AquatecOLIVIA, Schmidt A., Knobloch M.. Treatment and processing of residues from olive processing EU Life project. www.aquatec-engineering.com.

5. Aveni A.. Biogas recovery from olive-oil mill wastewater by anaerobic digestion. Anaerobic Digestion and Carbohydrate Hydrolysis of Waste. pp. 489-491. 1984.

6. Bayram A., Dumanoglu Y.. Evaluation of prina as fuel [in Turkish]. Proc. First Int. Symp. Environmental Problems in Olive Oil Production and Solutions. 7-9. June 2002. N. Azbar, N. Vardar, M. Akin, I. Cevilan. Balikesir University,

7. Bayram A.. Pirina as a renewable energy resource: The production, properties and evaluation [in Turkish]. Proc. Renewable Energy Sources Symposium. Chamber of Electrical Engineers Izmir Branch. 18-20. January 2001. pp. 108-112.

8. Beccari M., Bonemazzi F., Majone M., Riccardi C.. Interaction between acidogenesis and methanogenesis in the anaerobic treatment of olive oil mill effluents. Water Res.. 30; 183. (1996):

9. Beccari M., Majone M., Torrisi L.. Two-reactor system with partial phase separation for anaerobic treatment of 
olive oil mill effluents. Water Sci. Technol.. 38; 4-5; 53-60. (1998):

10. Beccari M., Majone M., Riccardi C., Savarese F., Torrisi L.. Integrated treatment of olive oil mill effluents: Effect of chemical and physical pretreatment on anaerobic treatability. Water Sci. Technol.. 40; 1; 347-355. (1999):

11. Beccari M., Majone M., Papini M. P., Torrisi L.. 2 Enhancement of anaerobic treatability of olive oil mill effluents by addition of $\mathrm{Ca}(\mathrm{OH}) 2$ and bentonite without intermediate solid/liquid separation. Water Sci. Technol.. 43; 11; 275-282. (2001): [PUBMED][INFOTRIEVE]

12. Bisignano G., Lagana M. G., Trombetta D., Arena S., Nostro A., Uccella N., Mazzanti G., Saija A.. Olea europaea In vitro antibacterial activity of some aliphatic aldehydes from Olea europaea L.. FEMS Microbiol. Lett.. 198; 1; 9. (2001): [CROSSREF][PUBMED][INFOTRIEVE]

13. Boari G., Mancini I. M., Trulli E.. Anaerobic digestion of olive mill effluent pretreated and stored in municipal solid waste sanitary landfills. Water Sci. Technol.. 28; 2; 27. (1993):

14. Bonazzi M.. Euro-Mediterranean policies and olive oil: Competition or job sharing. Executive Summary. EUR 17270 EN. 1996.

15. Borja R., Martin A., Alanso V., Garcia I., Banks C. J.. Influence of different aerobic pretreatments on the kinetics of anaerobic digestion of olive mill wastewater. Water Res.. 29; 2; 489. (1995):

16. Borja R., Banks C. J., Maestro-Duran R., Alba J.. The effects of the most important phenolic constituents of olive mill wastewater on batch anaerobic methanogenesis. J. Environ. Technol.. 17; 167-174. (1996):

17. Borja R., Alba J., Banks C. J.. Anaerobic digestion of wash waters derived from the purification of virgin olive oil using a hybrid reactor combining a filter and a sludge blanket. Process Biochem.. 31; 3; 219-224. (1996):

18. Borja R., Banks C. J., Khalfaoui B., Martin A.. Performance evaluation of an anaerobic hybrid digester treating palm oil mill effluent. J. Environ. Sci. Health A. 31; 6; 1379-1393. (1996):

19. Carrieri C., Balice V., Rozzi R.. Comparison of three anaerobic treatment processes on olive mills effluents. Proc. Int. Conf. Environment Protection. 1988.

20. Chakchouk M., Hamdi M., Foussard J. N., Debellefontaine H.. Complete treatment of olive mill wastewaters by a wet air oxidation process coupled with a biological step. Environ. Technol.. 15; 4; 323. (1994):

21. Cegarra J., Alburquerque J. A., Gonzalves J., Garcia D.. A survey of olive-mill wastes in Spain, feasibility of composting. Proc. First Int. Symp. Environmental Problems in Olive Oil Production and Solutions. 7-9. June 2002. N. Azbar, N. Vardar, M. Akin, I. Cevilan. Balkesir University,

22. Demicheli M., Bontoux L.. Survey current activity on the valorization of by-products from the olive oil industry. European Commission Joint Research Centre, Final Report. www.jrc.es/projects/ff/EC/IPTS/IPTSPUBL.html1996.

23. Dumanoglu $\mathrm{Y}$.. Investigation of pirina combustion in a test boiler for energy production. Unpublished MSc thesis. Dokuz Eylul University, Graduate School of Natural and Applied Sciences, 2003.

24. Duarte E. A., Neto I.. Evaporation phenomenon as a waste management technology. Water Sci. Technol.. 33; 8; 53. (1996):

25. Ergüder T. H., Güven E., Demirer G. N.. Anaerobic treatment of OMW in batch reactors. Process Biochem.. 36; 3; 243-248. (2000):

26. FAIR CT96-1420, Annex 2. Final report, Improlive, investments of treatment and validation of liquid-solid waste from the two phase olive oil extraction Final report, Improlive, investments of treatment and validation of liquidsolid waste from the two phase olive oil extraction. WwW.nf-2000.org/publications/q30011.pdf2000.

27. Filippi C., Bedini S., Levi-Minzi R., Cardelli R., Saviozzi A.. Co-compositng of olive oil mill by-products: Chemical and microbiological evaluations. Compost Sci. Utilization. 10; 1; 63-72. (2002):

28. Galili E., Sharvit J.. 20,000 Olives under the sea. Archaeol. Hist. Israel Discover. 19; 5; 16. (1998):

29. Georgacakis D., Dalis D.. Controlled anaerobic digestion of settled olive-oil wastewater. Bioresource Technol.. 46; 221. (1993):

30. Gharsallah N.. Influence of dilution and phase separation on the anaerobic digestion of olive mill wastewaters. 
Bioprocess Eng.. 10; 29. (1994):

31. Giannakas K., Tran K., C.. Efficiency, technological change and output growth in Greek olive growing farms: A Box-Cox approach. Appl. Econ.. 32; 909. (2000):

32. Gonzalez M. D., Moreno E., Quevedo J., Ramos A.. Studies on antibacterial activity of waste waters from olive oil mills (alpechin): Inhibitory activity of phenolic and fatty acids. Chemosphere. 20; 432. (1990):

33. Greco Jr. G., Toscanoa G., Cioffi M., Gianfreda L., Sannino F.. Dephenolisation of olive mill wastewaters by olive husk. Water Res.. 33; 3046. (1999):

34. Hamdi M.. Thermoacidic precipitation of darkly coloured polyphenols of olive mill wastewaters. Environ. Technol.. 14; 495. (1993):

35. Hamdi M.. Future prospects and constraints of olive oil mill wastewaters use and treatment, a review. Bioprocess Eng.. 8; 209. (1993):

36. Hamdi M., Garcia J. I., Ellouz R.. Integrated biological process olive oil mill wastewater treatment. Bioprocess Eng.. 8; 79. (1992):

37. Hamdi M.. Toxicity and biodegradability of olive mill wastewaters in batch anaerobic digestion. Appl. Biochem. Biotechnol.. 37; 155. (1992):

38. Henderson C. W.. Olive oil may prevent development of bowel cancer. Cancer Weekly. 23; (2000): [CROSSREF]

39. Improlive. 2000. http://www.fiw.rwth-aachen.de/improlive/rsanfall/abwasser/anaerob.html.

40. Israilides C. J., Vlyssides A. G., Mourafeti V. N., Karvouni G.. Olive oil wastewater treatment with the use of an electrolysis system. Bioresource Technol.. 61; 2; 163. (1997):

41. Iza J., Colleran E., Paris M. J., Wu W. M.. International workshop on anaerobic treatment technology for municipal and industrial wastewaters: Summary papers. Water Sci. Technol.. 24; 8; 1-16. (1991):

42. Johnson B., Balserak P., Beaulieu S., Cuthbertson B., Steward R., Truesdale R., Whitmore R., Young J.. Industrial surface impoundments: Environmental settings, release and exposure potential and risk characterization. Sci. Total Environ.. 317; 1-3; 1-22. (2003): [CROSSREF][PUBMED][INFOTRIEVE]

43. Kasirga E.. Treatment of olive oil industry wastewaters by anaerobic stabilization method and development of kinetic model [in Turkish]. Unpublished PhD thesis. Dokuz Eylul University, Graduate School of Natural and Applied Sciences, 1988.

44. LED Italia. Olive mill water treatment through vacuum evaporation. Technical report 7, LED Italia s.r.I.. 1997.

45. Longhi P., Vodopivec B., Fiori G.. Electrochemical treatment of olive oil mill wastewater. Ann. Chim.. 91; 3-4; 169. (2001): [PUBMED][INFOTRIEVE]

46. Marques I. P., Teixeira A., Rodrigues L., Martins Dias S., Novais J. M.. Anaerobic treatment of olive mill wastewater with digested piggery effluent. Water Res.. 70; 5; 1056. (1998):

47. Martin J., Moreno M.. The role of olive oil in lowering cancer risk: Is this real gold or simply pinchbeck. J. Epidemiol. Commun. Health. 54; 10; 721. (2000):

48. Masghouni M., Hassairi M.. Energy applications of olive oil industry by-products:-l. The exhaust foot cake. Biomass Bioenergy. 18; 257-262. (2000):

49. Muezzinoglu A., Uslu O.. Alleviation of pollution due to olive oil production, some practical considerations from Turkey. International Symposium on Olive By-Products Valorization. Food and Agriculture Organization of the United Nations, pp. 159-168. 1986.

50. Mulinacci N., Romani A., Galardi C., Pinelli P., Giaccherini C., Vincieri F. F.. Polyphenolic content in olive oil wastewaters and related olive samples. J. Agric. Food Chem.. 49; 8; 3509. (2001):

[CROSSREF][PUBMED][INFOTRIEVE]

51. Nychas G. J.E., Tassou C., Board R. G.. Staphylococcus aures Phenolic exctract from olives: Inhibition of Staphylococcus aures. Lett. Appl. Microbiol.. 10; 217. (1990):

52. Newmark H. L.. Squalene, olive oil and cancer risk: A review and hypothesis. Cancer Epidemiol. Biomarkers 
Prevent.. 6; 1101. (1997):

53. Oktav E., Sengul F.. A study on treatability of olive mill wastewaters [in Turkish]. ITU 7. Endustriyel Kirlenme Kontrolu Sempozyumu 2000. Proceedings of Industrial Pollution Symposium 2000. pp. 51-58. Istanbul Technical University, 2000.

54. Patumsawad S., Cliffe K. R.. Experimental study of fluidized bed combustion of high moisture municipal solid waste. Energy Combust. Manage.. 43; 17; 2329-2340. (2002):

55. Ranalli A.. Microbial treatment of oil mill waste waters. Grasas Acetes. 43; 16. (1992):

56. Rivas F. J., Beltrán F. J., Gimeno O., Frades J.. Treatment of olive oil mill wastewater by Fenton's reagent. J. Agric. Food Chem.. 49; 4; 1873. (2001): [CROSSREF][PUBMED][INFOTRIEVE]

57. Rozzi A., Malpei F.. Treatment and disposal of olive mill effluents. Int. Biodeterior. Biodegrad.. 38; 3-4; 135. (1997):

58. Rozzi A., Santori M., Spinosa L.. Anaerobic digestion in Italy with special reference to treatment of olive oil mill wastes. Anaerobic Digest. Sewage Sludge Org. Agric. Wastes. 55-65. 1986.

59. Samsunlu A., Tünay O., Öztürk Z., Alp K.. Characterization and treatability of olive oil wastewaters (in Turkish), I.T.Ü. 6. Industrial Pollution Symp. Proc.. pp. 93-99. 1998.

60. Sengul F.. Industrial wastewater characteristics and treatment [in Turkish]. Faculty of Engineering Textbook Series. Dokuz Eylul University Faculty of Engineering Press, 1991.

61. Sengul F., Oktav E., Cokay E.. Treatment of olive oil mill wastewaters and beneficiation of the by-products [in Turkish]. 2000 GAP-Environment Congress Proc.. Harran University, 2, 713; 16-18. 2000.

62. Scioli C., Vollaro L.. Yarowia lipolytica The use of Yarowia lipolytica to reduce pollution in olive mill wastewaters. Water Res.. 31; 10; 2520. (1997):

63. Skiadas I. V., Lyberatos G.. The periodic anaerobic baffled reactor. Water Sci. Technol.. 38; 8-9; 401-408. (1998):

64. Tsonis S. P., Grigoropoulos S. G.. Anaerobic treatability of olive oil mill wastewater. Water Sci. Technol.. 28; 2; 35. (1993):

65. Tuncel G., Nergiz C.. Antimicrobial effect of some olive phenols in a laboratory medium. Lett. Appl. Microbiol.. 37; 155. (1993):

66. Turkish Air Pollution Control Regulation. Official Gazette. 19269. 2 November 1986.

67. Turkish Water Pollution Control Regulation. Official Gazette. 19919. 4 September 1988.

68. Ubay B., Ozturk I.. Anaerobic treatment of olive mill effluents. Water Sci. Technol.. 36; 2-3; 287. (1997):

69. Uyanik S.. Process performance and bacterial population dynamics in conventional and modified anaerobic baffled reactors treating industrial wastewaters. Unpublished PhD thesis. University of New Castle, 2001.

70. Vlyssides A. G., Loizides M., Karlis P. K.. Integrated strategic approach for reusing olive oil extraction byproducts. J. Cleaner Prod.. (in press):

71. Wellman T.. Replenishing your immune system with nature's antibiotic apothecary. Total Health. 23; 6; 76. (2001):

72. Yesilada O., Fiskin K., Yesilada E.. Funallia trogii The use of white rot fungus Funallia trogii (Malatya) for the decolorization and phenol removal from olive mill wastewater. Environ. Technol.. 16; 95. (1995):

73. Zouari N., Eloouz R.. Toxic effects of colored olive compounds on the anaerobic digestion of olive mill effluent in UASB-like reactors. J. Chem. Technol. Biotechnol.. 66; 4; 414. (1999):

74. Zuberbuehler U., Berger R., Baumbach G., Hein K. R.G., Bayram A.. Combustion performance with residues of olive oil production in three different firing systems for decentralized process heat generation. 1st World Conf. Exhibition on Biomass for Energy and Industry. 5-9. June 2000. 8; 48; 